$11-1989$

\title{
Copyright Protection for ASIC Gate Configurations: PLDs, Custom and Semicustom Chips
}

Glynn S. Lunney Jr

Texas A\&M University School of Law, glunney@law.tamu.edu

Follow this and additional works at: https://scholarship.law.tamu.edu/facscholar

Part of the Law Commons

\section{Recommended Citation}

Glynn S. Lunney Jr, Copyright Protection for ASIC Gate Configurations: PLDs, Custom and Semicustom Chips, 42 Stan. L. Rev. 163 (1989).

Available at: https://scholarship.law.tamu.edu/facscholar/437

This Article is brought to you for free and open access by Texas A\&M Law Scholarship. It has been accepted for inclusion in Faculty Scholarship by an authorized administrator of Texas A\&M Law Scholarship. For more information, please contact aretteen@law.tamu.edu. 


\title{
Copyright Protection for ASIC Gate Configurations: PLDs, Custom and Semicustom Chips
}

\author{
Glynn S. Lunney, Jr.*
}

Conventional wisdom holds that computer software and computer hardware require two different species of intellectual property protection. Software is thought best protected by copyright law, while hardware is thought best protected by patent law, trade secret law or the Semiconductor Chip Protection Act of 1984. Recent technological and legal developments blur software-hardware distinctions, as courts have extended copyright protection to object code, firmware and microcode, and patent protection to software. This note argues that the standard industry conceptions of hardware and software are inadequate to answer the legal question of what is copyrightable as a computer program. Furthermore, it considers whether application specific integrated circuits (ASICs), which are, typically, semi-custom hardware solutions to engineering design problems traditionally solved in software, should qualify as computer programs for purposes of copyright protection.

The rules of copyright historically have covered a wide variety of works, from nautical maps to poetry to sculpture to painting. ${ }^{1}$ Each new work has presented a challenge to the courts, a challenge to provide the appropriate protection for each type of work within the general policies that the copyright law represents. Courts have faced a new challenge as a result of the formal recognition in 1980 of computer programs as a form of copyrightable literary work. ${ }^{2}$

This challenge can be broken down ${ }^{3}$ into providing a proper bal-

* Third-year student, Stanford Law School. I would like to thank Paul Goldstein, Ron Laurie, and Dan Siegel for their help with the issues.

1. See H.R. REP. No. 1476, 94th Cong., 2d Sess. 51, 51-57 (1976), reprinted in 1976 U.S. Code Cong. \& Admin. News 5659, 5659-70 [hereinafter Copyright Report].

2. Act of Dec. 12, 1980, Pub. L. No. 96-517, § 10, 94 Stat. 3015, 3028 (codified as amended at 17 U.S.C. $\$ \$ 101,117$ (1987)).

3. This breakdown relies on an economic approach to copyright, setting up a copyright system which provides the appropriate incentives for the production of these works. See, e.g., Harper \& Row, Publishers v. Nation Enters., 471 U.S. 539, 546 (1985) ("The rights conferred by copyright are designed to assure contributors to the store of knowledge a fair return for their labors."); Sony Corp. of Am. v. Universal City Studios, 464 U.S. 417 (1984).

The monopoly privileges that Congress may authorize are neither unlimited nor primarily designed to provide a special private benefit. Rather, the limited grant is a 
ance between the public's desire for a free flow of ideas and the author's desire for recognition and reward for her creative effort, and at the same time, ensuring that the system of protection established does not create incentives inconsistent with the social value of the work. ${ }^{4}$ These two principles, the balance between author and society and the correlation between incentives and societal value, will be referred to respectively as the proper level of investment and the proper direction for investment.

In approaching the challenge of protecting computer programs under the copyright law, commentators have substituted, at times without reflection, computer software for computer program as the work included within copyright. Such commentators exclude computer hardware from the realm of copyright and relegate it to another system of intellectual property protection, such as patent or trade secret. ${ }^{5}$ They perceive a continuum with software ${ }^{6}$ at one end and hardware ${ }^{7}$ at the other. And source code, perhaps because of its similar appearance to works written in human languages, most clearly deserves copyright protection, while hardware, perhaps because of its more industrial pedi-

means by which an important public purpose may be achieved. It is intended to motivate the creative activity of authors and inventors by the provision of a special reward, and to allow the public access to the products of their genius after the limited period of exclusive control has expired.

Id. at 429; see also Twentieth Century Music Corp. v. Aiken, 422 U.S. 151, 156 (1975); Mazer v. Stein, 347 U.S. 201, 219 (1954); United States v. Paramount Pictures, 334 U.S. 131, 158 (1948). Other approaches might focus on rewarding the author or ensuring an appropriate relationship between an author and her work. See generally Glynn S. Lunney, Jr., A Critique of the Use of Economic Analysis in Copyright (Aug. 14, 1989) (unpublished manuscript) (student author) (on file with the Stanford Law Review).

4. On the balance between society and the author, see 1 PaUl Goldstein, Copyrigrt $\S 1.1$ (1989). The directions principle is a bit more complex but derives basically from the notion that the incentive system should be neutral as between two works that are similar, despite the fact that one appears to be more clearly art. Cf. Bleistein v. Donaldson Lithographing Co., 188 U.S. 239, 251-52 (1903). Social or societal value of a work is used throughout this paper as the economic value to society of the work created. This term is necessarily slippery, but market value as the integrated area under the work's demand curve will suffice assuming that each person along the demand curve had to pay for the work, i.e., that the public good nature of the work is not affecting that curve.

5. See, e.g., Bruce Perelman, Proving Copyright Infringement of Computer Software: An Analytical Framework, 34 CopYRIGHT L. SYMP. (ASCAP) 99 (1987) (student author); $c f .1$ MELVILLE B. Nimmer \& David Nimmer, Nimmer on Copyright $\$ 2.18$ (F) (1988); 3 id. § 18.02(B).

6. Since a good portion of this note argues that a conceptual line between hardware and software should not be recognized legally, it would be somewhat foolish to define the term "software" at this point. Suffice it to say that in this note the term refers to those things generally considered protected by copyright as computer programs. This does not refer to the technical support manuals or instructions, but only to code, either source or object code, which when input into a computer makes the computer perform certain functions. I also will use the term "software program" with the same meaning.

7. Keeping in mind the limitations set out above, "hardware" as used in this note refers to those elements generally not considered protected by copyright, specifically, electrical circuits embedded in silicon. That term generally does not include the various peripherals and interfaces (video monitor, disk drives, keyboard, mouse, and the like) that turn the hardware into a computer. 
gree, ${ }^{8}$ clearly does not.

At each step away from source code, and seemingly towards hardware, the courts were called upon to decide if this step went too far. The first tentative step was taken with object code, which is a series of 1 's and 0's that the computer can read directly.9 This was followed quickly by firmware, which is a software program stored on a memory chip. ${ }^{10}$ Recently, another step has been taken in the form of microcode, a set of written instructions embodied in the microprocessor chip that controls the inner workings of the central processing unit. ${ }^{11}$ While the courts readily took each step, commentators argued that each step went too far. ${ }^{12}$

Logic circuits represent the last step to be taken in getting all the way to the computer hardware end of the continuum. ${ }^{13}$ It is a step that this note argues should be taken. Specifically, the note focuses on design methods and appropriability concerns for application specific integrated circuits (ASICs), which for the purposes of this note include custom and semicustom chips, as well as programmable logic devices (PLDs). ${ }^{14}$

As their name indicates, ASICs are chips designed to perform specific tasks. For example, these chips can be found in various personal computers currently on the market, providing sequencing and execution control, duplicating the functions of an operating system, or performing any number of other tasks necessary to tie the microprocessor into a system where a user can harness its power. ${ }^{15}$ Deciding whether

8. Thus, the title of the author, whether electrical engineer or computer scientist, could spell the difference between a work receiving copyright protection or not. At least that would be one interpretation of the rule.

9. See Apple Computer v. Franklin Computer Corp., 714 F.2d 1240, 1249, 1252 (3d Cir. 1983) (object code is a computer program within the meaning of $\$ 101$ ), cert. dismissed, 404 U.S. 1033 (1984); Williams Elec. v. Artic Int'l, 685 F.2d 870, 876-77 (3d Cir. 1982) (same); Midway Mfg. Co. v. Strohon, 564 F. Supp. 741, 750-51 (N.D. Ill. 1983) (same); Hubco Data Prods. Corp. v. Management Assistance, 219 U.S.P.Q. (BNA) 450, 454 (D. Idaho 1983) (same); GCA Corp. v. Chance, 217 U.S.P.Q. (BNA) 718, 719-20 (N.D. Cal. 1982) (same).

10. See Apple Computer, 714 F.2d at 1249, 1252 (firmware is a copy of the object code); IIilliams Elec., 685 F.2d at 876-77 (same); Midway Mfg. Co., 564 F. Supp. at 750-51 (same); Tandy Corp. v. Personal Micro Computers, 524 F. Supp. 171, 173 (N.D. Cal. 1981) (same). Note that the industry definition presupposes the legal answer in that it focuses on the program being stored in a chip rather than the chip containing a program. Taking the second tack, firmware is a chip that emits a voltage signal as if it were the object code stored in a random access memory.

11. See NEC Corp. v. Intel Corp., No. C-84-20799-WPG, slip op. at 3-6 (N.D. Cal. Feb. 6, 1989) (microcode is a computer program within the scope of $\$ 101$ ).

12. See, e.g., Robert C. Hinckley, NEC v. Intel: Irill Hardware Be Drawn into the Black Hole of Copyright?, 3 Santa Clara Computer \& High Tech. L.J. 23, 29-38 (1987); Pamela Samuelson, CONTU Revisited: The Case Against Copyright for Computer Programs in Machine-Readable Form, 1984 Duke L.J. 663, 705-53; Mark Friedman, Copyrighting Machine Language Computer Software-The Case Against, 26 Hous. L. Rev. 275, 295-96 (1989) (student author).

13. For a more detailed discussion of the possible dividing lines between hardware and software, see text accompanying notes 19-38 infra.

14. For an explanation of PLDs, see text accompanying notes 28-30 infra.

15. See,e.g., John Martin Birkner, The Evolution of PALs, BYTE, Jan. 1987, at 208. 
copyright protects ASICs is important for two reasons. First, other forms of intellectual property, such as patent and trade secret, do not seem to protect adequately these works. ${ }^{16}$ Second, market estimates indicate that ASICs may command 50 percent of the worldwide integrated circuit market by $1990 .{ }^{17}$

The heart of the argument for copyright protection for ASICs is simple-source code, object code, firmware, and logic circuits are all different ways of achieving a gate configuration through which an electrical signal can flow to produce a result, in some cases the same result. ${ }^{18}$ Because they all require similar intellectual and financial investments to create, face similar risks of nonappropriability of investment due to uncompensated use, and contain in equal parts elements important to the production of future works, they should all be protected under the same scheme of intellectual property protection. The argument will be taken in pieces: In section II.A., I will show that ASICs satisfy the formal requirements to obtain copyright protection, followed by an argument in section II.B. that both the level of and direction for incentives principles justify that protection, and concluding

16. While a full discussion of the possibilities of patent, trade secret, and the Semiconductor Chip Protection Act are beyond the scope of this note, I would like to make a few points concerning their potential weaknesses for ASIC protection. The circuits in ASICs would not usually satisfy patent's higher standards for protection. See Copyright Protection for Semiconductor Chips: Hearings on H.R. 1028 Before the Subcomm. on Courls, Civil Liberties, and the Administration of Justice of the House Comm. on the Judiciary, 98th Cong., Ist Sess. 64 (1983) [hereinafter Chips Hearings] (testimony of Gerald J. Mossinghoff) ("[T]he circuits in chips are usually well known and, therefore, unpatentable."). Moreover, trade secret protection is available only until the circuit designs are disclosed or a chip containing the circuits is sold in a public market. Id. at 64 . Also, assuming copyright and trade secret provide the same level of returns, copyright is preferable because it provides an option of licensing or reinvention, whereas with trade secret only reinvention is available, since it is difficult to license something of which one is unaware. Protection under the Semiconductor Chip Protection Act (SCPA), Pub. L. No. 98-620, 98 Stat. 3335 (codified as 17 U.S.C. $\$ \S 901-915$ (Supp. 1987)), may be available for custom or semicustom ASICs but not for programmable logic devices. See 17 U.S.C. $\$ 901$ (a)(2) (Supp. 1987) (definition of protectible subject matter); see also Ronald S. Laurie, The First Year's Experience Under the Chip Protection Act or "Where Are the Pirates Now that We Need Them?", The CompuTER LAw., Feb. 1986, at 11, 18. But the SCPA protects only the three dimensional gate layout on the chip, not the "program" (sequential logic) inherent in the design of the gate configuration, which is the focus of this note. See 17 U.S.C. $\$ 901$ (a)(2)(A) (Supp. 1987). Evidence from the marketplace also suggests that the protection provided through these systems is generally inadequate. See text accompanying notes 129-142 infra.

17. Phillip Robinson, Overview of Programmable Hardware, BYTE, Jan. 1987, at 197. See also Valerie Rice, The ASIC Market: Paradise Yesterday, War Zone Today, Electronic Bus., Jan. 1, 1988 , at 30, 34 (\$10 billion market by 1990); David Simpson, Tailoring Your System: The ASIC Edge, MiNi-Micro SYs., Nov. 1986, at 115 (\$7.2 billion market; 35\% of worldwide integrated circuit market).

18. Other commentators have recognized that software and hardware are functionally interchangeable. See John R. Harris, Legal Protection for Microcode and Beyond: A Discussion of the Applicability of the Semiconductor Chip Protection Act and the Copyright Laws to Microcode, 6 CoMpuTER L.J. 187, 191 (1985); Dennis S. Karjala, Copyright, Computer Software and the New Protectionism, 28 Jurimetrics J. 33, 36-40 (1987); Samuelson, supra note 12, at 675 n.38. See generally James A. Sprowl, Proprietary Rights in Programmed Computers: Looking Beyond the Hardware/Software Distinction for More Meaningful Ways of Characterizing Proprietary Interests in Digital Logic Systems, 1983 ARIz. ST. L.J. 785. 
with a general discussion in section II.C. of the proper scope for that protection. Before getting into the argument for protection, consider section I, which lays out both the relevant aspects of the technology and the development of copyright protection for computer programs since the 1980 amendments.

\section{The Early Struggles with the Hardware-Software Line}

While in some ways the difference between hardware and software is intuitively clear, intuition alone cannot suffice as a legal standard to differentiate hardware from software. ${ }^{19}$ Prospective investors require a clear standard so that they can know in advance what sort of protection, if any, the works in which they invest will receive. Arguably, a legal line between hardware and software may be drawn based either on the method of creation, or on the technical differences between logic and memory. To understand these two conceptual bases, a brief review of some aspects of computer technology will be helpful.

\section{A. The Relevant Technology}

\section{The situation at hand.}

Transistors are one of the building blocks for all semiconductor chips. They are tiny electronic devices "capable of amplifying electrical signals and acting as an electrical switch."20 Transistors can provide a high or low voltage which can be represented by Boolean logic ${ }^{21}$ or the binary system. By tying the transistors together, we can construct gates that perform basic logical functions. Three elementary gates provide the basis for logic and memory circuits: AND gates, OR gates and inverters. Combining the inverter with either the AND or the OR gate produces their logical complements, the NAND gate or the NOR gate respectively. From these gates, all other gates may be created. ${ }^{22} \mathrm{~A}$ chip design is created by tying together the appropriate gates to achieve the desired gate configuration or circuit.

Circuits may be classified as logic or memory circuits. While the

19. Nor is it sufficient to say that one is a machine and the other is not, because the technology is not straightforward in that way. Both software and hardware affect the flow of electricity in a computer. Cf. Midway Mfg. Co. v. Strohon, 564 F. Supp. 741, 751-52 (N.D. Ill. 1983) ("The fact that ... electrical current moves through a silicon chip rather than being remotely directed in its movement by information on a tape or disk, does not in our view serve as a tenable basis for concluding that a ROM is somehow more 'utilitarian'....").

20. Chips Hearings, supra note 16, at 22 (statement of F. Thomas Dunlap, Jr., Corporate Counsel and Secretary, Intel Corp.).

21. In 1847, George Boole developed symbolic logic or "Boolean" algebra, which is a method of analyzing logical statements by treating each statement as either true or not true. See genetally Harold E. Ennes, Boolean Algebra for Computer logic (1978); H. Graham FlegG, Boolean Algebra and Its Applications (1964).

22. See Warren Fenton Stubbins, Essential Electronics 6-16 (1986). 
same electrical rules govern both types of circuits, ${ }^{23}$ they perform different functions within the chip architecture. Logic circuits electronically perform information processing functions while memory circuits simply store data or object code. ${ }^{24}$ A chip may contain both memory and logic circuits. ${ }^{25}$

To focus the discussion an introduction of some of the major characters is in order: they are programmable read only memory chips, programmable logic devices, custom chips, and semicustom chips.

Programmable read only memory chips (PROMs) are commonly used to store object code. The circuitry in a PROM consists of an array of AND gates and an array of OR gates. To store object code in a PROM, the object code is fed into a special programming machine which breaks connections on the OR array so that each line of the object code can be reproduced from the PROM. ${ }^{26}$ Thus, the final gate configuration of the PROM is determined by the combination of the blank array of AND and OR gates and use of the object code to "program" the OR array. And it is this combination which is firmware. ${ }^{27}$

Programmable logic devices (PLDs) also consist of a paired array of AND and OR gates. ${ }^{28}$ The two basic forms are programmable logic arrays (PLAs), in which both gate arrays are programmable, and programmable array logic (PALs), in which only the AND gate array is programmable. ${ }^{29}$ Where a PROM is programmed generally with an object code version of a software program, a PLD is programmed with either Boolean equations or some higher level logic description language. ${ }^{30}$

Custom and semicustom chips have gates configured to achieve the logic pattern desired by a purchaser. To achieve the final gate configu-

23. See, e.g., Robinson, supra note 17, at 197-98; Daniel R. Siegel, A First Look at Copyright Protection for Computer Hardware, COMPUTER LAw., Dec. 1987, at 1, 8-9.

24. See Chips Hearings, supra note 16, at 21 (statement of F. Thomas Dunlap, Jr.); see also id. at 101 (statement of Dorothy Schrader, Assoc. Register of Copyrights).

25. See id. at 22 (statement of F. Thomas Dunlap, Jr.) ("Of course, the functions of a microprocessor and a memory can be integrated on the same semiconductor chip.").

26. See 2 Edwin E. Klingman, Microprocessor Systems Design: Microcoding, ArRay Logic, AND ARChitectural DESIGN 84-87 (1982). Note that while PROMs are often characterized as memory chips, they may also perform logical functions. See Vincent J. Coli, Introduction to Programmable Array Logic, BYTE, Jan. 1987, at 207, 207 ("the PROM is also ideal for logic applications requiring less than 10 inputs"); Robinson, supra note 17, at 197 ("a ROM can function as a logic device").

27. See, e.g., Midway Mfg. Co. v. Strohon, 564 F. Supp. 741, 751 (N.D. Ill. 1983). Other cases that refer to memory circuits "storing" programs are referring to firmware. See, e.g., Stern Elecs. v. Kaufman, 669 F.2d 852, 854 (7th Cir. 1982) (storage of instructions and data on a PROM); Apple Computer v. Formula Int'l, 562 F. Supp. 775, 778 (C.D. Cal. 1983) (discusses creation of ROM from object code), aff'd, $725 \mathrm{~F} .2 \mathrm{~d} 521$ (9th Cir. 1984); see also note 10 supra. See generally Stanley G. Burns \& Paul R. Bond, Principles of Electronic Circuits $371-76$ (1987).

28. See 2 E. KLingman, supra note 26 , at 84-87.

29. See id. at 86.

30. See Bernard C. Cole, Programmable Logic Devices: The Second Generation, ElECTRonics, May 12, 1988, at 61, 61-63; Robinson, supra note 17, at 201; Simpson, supra note 17, at 116. 
rations of custom and semicustom chips designers generally use hardware description languages and computer-aided design rather than the traditional method of drawing schematic diagrams.

To design full-custom chips, Boolean equations derived from the desired specifications of a prospective purchaser are written out and entered into a silicon compiler. The compiler generates the chip design in the form of a layout. ${ }^{31}$ The layout can be debugged through computer simulation and the result run through a production process to create the final gate configuration on a previously blank wafer of silicon. ${ }^{32}$

For semicustom chips, two general design methods are available: gate arrays and standard cells. In the case of a gate array, the initial three-quarters of the chip are created using general specifications. The remainder, usually one to four layers, is then customized using a process similar to that used to create a full-custom chip, with functions broken out and the necessary Boolean equations developed. ${ }^{33}$ The set of equations is entered into a compiler that can create the final gate layout. The final gate layout is then used to lay down the last quarter of the gate configuration.

The standard cell design method begins with a blank slate, like fullcustom chips. However, rather than designing with individual gates, the designer uses a library of building blocks, each of which represents a group of gates tied together to perform a specific logic or memory function. ${ }^{34}$ This procedure is analogous to object oriented programming in software development. ${ }^{35}$

Returning briefly to the notion that copyright protection should attach depending on the method of creation, while circuit diagrams and source level programming appear easily differentiable, not so the method for creating ASICs as compared to the method for creating conventional software. Equations fed into the silicon compilers used to create ASICs look "a lot like programs written in Fortran or C," 36 two source code languages used to write software programs. As a general

31. See Robert A. Freedman, Getting Started with PALs, Byte, Jan. 1987, at 223, 224; Robinson, supra note 17 , at $199-200$.

32. For an account of mask-based production, see Chips Hearings, supra note 16, at 22-25 (statement of F. Thomas Dunlap, Jr.). For a discussion of more advanced possibilities, see Chips Hearings, supra note 16, at 99 (statement of Dorothy Schrader) ("[I]t is now possible to 'write' the patterns directly on a wafer using electron-beam technology.").

33. See Robinson, supra note 17, at 200; Simpson, supra note 17, at 116-17.

34. See Robinson, supra note 17, at 200; Simpson, supra note 17, at 120.

35. See, e.g., Maria Shao \& Geoff Lewis, Apple Turns from Revolution to Evolution, Bus. WK., Jan. 23, 1989, at 92 (Hypercard); . . And Asymetrix Will Let 'em Become Real Sophisticates, Bus. WK., Mar. 20, 1989, at 152E.

36. Freedman, supra note 31, at 230; see also Otis Port, Do-It-Yourself Chips Get Easier, Bus. Wk., Mar. 30, 1987, at 92; Steve Trimberger \& Jim Rowson, CAD for Building Chips, BYTE, June 1987, at 217,217 . Note that similar progress is being made in the design of general logic chips. See generally Computer, Feb. 1985 (entire issue); Jeremy Young, VHDL: The Lingua Franca of Design?, Electronics, May 12, 1988, at 32, 32. 
observation, object code and Boolean equations, source code and silicon compilers, object oriented programming and standard cells, and programming a PROM and programming a PLD all are software and hardware design equivalents. Each pair reflects fundamentally the same method of creating a final gate configuration to produce a result. Thus, even those in the computer industry often cannot agree whether to label any given product as software or hardware. ${ }^{37}$

In comparison, the functional difference between logic (processing data) and memory (storing data) remains a viable conceptual line upon which to divide hardware and software. Whether this line should be the basis of deciding the legal issue of copyright protection remains to be determined. ${ }^{38}$

\section{The situation in perspective.}

Before discussing the courts' early struggles with the hardwaresoftware line, the hardware-software line must be put in perspective. The hardware-software line has not always been a part of computer technology. The original computers were hardwired and contained no conventional software. ${ }^{39}$ The advent of the general purpose computer created the need for software. Without software, a general purpose computer was merely a bunch of wiring; however, software could configure the wiring in such a manner so as to convert the "bunch of wiring" into a machine capable of performing various desired functions. ${ }^{40}$ Hardware has continued to advance with the invention of the semiconductor chip in 1959 and the microprocessor chip in 1971. The latest generation of chips "have more computing power, compute faster, consume far less power, are more reliable, and sell for a fraction of the cost of mainframe computers of the early 1970's." 41

The computer industry recognizes the current generation of computers as the fourth. Researchers expect the fifth generation to consist of computers capable of more accurately duplicating the human thought process through the use of parallel architecture. Future generations may function more like biological systems, with molecular transistors and memory systems based on optics rather than electricity. ${ }^{42}$

37. Compare Trevor G. Marshall, PALs Simplify Complex Circuits, BYTE, Jan. 1987, at 247, 247 ("The PAL is a software element, not a hardware device."), with Freedman, supra note 31, at 223 ("Anyone doing digital logic design with TTL these days ought to be using PALs.").

38. The logic-memory dichotomy plays out through the copyright dichotomy between the work and a copy of that work. See text accompanying notes 76-92 infra. For an argument that the logic-memory dichotomy should be the legal dividing line, see Daniel R. Siegel \& Ronald S. Laurie, Beyond Microcode: Alloy v. Ultratek-The First Attempt to Extend Copyright Protection to Computer Hardware, Computer LAW., Apr. 1989, at 1, 12-13.

39. See, e.g., Friedman, supra note 12, at 277-78.

40. Id.

41. H.R. REP. No. 781, 98th Cong., 2d Sess. (1984), reprinted in 1984 U.S. Code ConG. \& Admin. News 5750, 5760 [hereinafter Chips Report].

42. Staff of Senate Subcomm. on Patents, Copyrights and Trademarks of the Senate Comm. on the Judiciary, 99th Cong. 1st Sess., Proceedings of the Congressional 
The question remains whether there always will be a hardware-software line or whether it is merely a transitory stage in the evolution of computer technology.

Consider, for example, patent number $4,802,103$. This patent describes circuitry that can associate new events with ones it has "experienced" before. This is made possible through the use of programmable electrical switches. These circuits "learn" by increasing the electrical charge stored at those switches that experience repeated use. Thus, computer designers may create neural networks which "recognize" events by comparing the pattern of electrical activity generated by one event with the patterns generated by previous events. ${ }^{43}$ This capability raises such questions as whether these neural networks are protectible by copyright as computer programs; and, whether the network contains any identifiable line between hardware and software. Fortunately, these questions need not be answered here and now, but we must keep in mind that the incentive structure created by the law here and now will affect the chances of such advances coming to pass.

\section{B. A Brief History of the Legal Status of the Hardware-Software Line}

As a starting point, it remains unclear on what legal basis the hardware-software line has been drawn. A 1980 amendment to the 1976 Copyright Act defines a computer program as "a set of statements or instructions to be used directly or indirectly in a computer to bring about a certain result," 44 mentioning neither hardware nor software. Apparently, Congress opted to avoid a narrow definition in order to provide flexibility in the face of inevitable innovation. ${ }^{45}$ While in its silence Congress might have intended not to include hardware, a machine, under copyright, there is some indication that Congress, acting on the recommendation of the National Commission on New Technological Uses (CONTU), intended to leave this and other difficult linedrawing issues for the courts. ${ }^{46}$

The Copyright Office has refused thus far to register gate configurations if developed using conventional hardware design and fixed on a chip. ${ }^{47}$ The courts, in turn, have struggled with what things other than

Copyright and Technology Symposium 63 (Comm. Print 1985) [hereinafter Copyright \& TECHNOLogY Symposium].

43. See Edmund Andrews, Computers That Mimic the Human Brain, San Francisco Chron., Feb. 11, 1989, at A5, col. 1 .

44. 17 U.S.C. \$ 101 (1982).

45. See National Commission on New Technological Uses of Copyrighted Works, FinAl RePORT 25 (1979) [hereinafter CONTU Final RePORT]. Courts have divided on how to treat CONTU's work. Compare Apple Computer v. Formula Int'l, 725 F.2d 521, 524 (9th Cir. 1984) (CONTU's report part of the legislative history and relied on as authority), with Whelan Assocs. v. Jaslow Dental Lab., 797 F.2d 1222, 1241-42 (3d Cir. 1986) (CONTU's report should not enter into determination of idea-expression boundary for computer program), cert. denied, 479 U.S. 1031 (1987).

46. See CONTU FINAL RePort, supra note 45, at 22-23.

47. See Chips Hearings, supra note 16, at 88 (statement of Dorothy Schrader). Intel sought 
source code should fall within the definition of computer program, generally relying on method of creation as a guide. In one early decision denying protection to PROMs, Judge Newcomer described the necessary examination as follows:

(I)n the case of the programs on ROM, did the programmer-designer imagine the architectural structure of the ROM, the overlay of microswitches [i.e., transistors] that would be most economical and efficient for the system, or did he envision the flow chart of operations which the program would perform? If the former, the programmer may be said to have been an engineer designing a utilitarian aspect of the machine. If the latter, the programmer may not be said to have designed the architecture of the chip..$^{48}$

Though Judge Newcomer stated a fairly clear "means of creation" test, he applied it incorrectly, holding that an operating system in object code form stored on a PROM was not protectible. 49 The Third Circuit reversed and held that the object code version of the operating system was a program and that it was fixed on the PROM..$^{50}$

The Third Circuit's decision, though correct, provides little guidance for future cases. If courts should merely focus on some form of the initial work-looking for a writing that resembles conventional software, and finding it, take no steps to determine if it is fixed in the particular silicon chip, then protection results from "medium" and not "message." 51 In other words, if the creator submits schematics of a circuit that resemble architectural drawings, then a copyright in those drawings will not protect the circuits. But if, however, the creator submits a "set of statements" embodying the step-by-step function of the circuits and that set of statements adequately resembles a source code version of a software program, then a copyright in the set of statements will protect the resulting circuit.

One court's decision concerning microcode suggests that this might indeed be the case, though without explicitly referring to the method of creation in determining whether a gate configuration should be copyrightable. ${ }^{52}$

to have a court mandate registration for its chips, but voluntarily dismissed the case. See Intel Corp. v. Ringer, No. 77-2848 (N.D. Cal. Oct. 10, 1978) (voluntarily dismissed).

48. Apple Computer v. Franklin Computer Corp., 545 F. Supp. 812, 820-21 (E.D. Pa. 1982), rev'd, 714 F.2d 1240 (3d Cir. 1983), cert. dismissed, 464 U.S. 1033 (1984).

49. Apple Computer, $545 \mathrm{~F}$. Supp. at 821-24. The decision can also be seen as a failure of Apple to satisfy the likelihood of success on the merits element for a preliminary injunction. Id. at 825 .

50. See Apple Computer, 714 F.2d at 1249.

51. The medium and message reference comes from language in Apple Computer, where the court indicated that the fact that the claimed program looked like a piece of hardware was not controlling. See id. at 1251 . I also use it as a reminder that the fact that one designer draws out the final gate configuration while another uses a source code to create it should not determine that the first designer cannot receive copyright protection.

52. The court's only reference to method of creation is in the language indicating that a set of statements did exist to satisfy the statutory definition. NEC Corp. v. Intel Corp., No. C84-20799-WPG, slip op. at 3-8 (N.D. Cal. Feb. 6, 1989) (indicating that the presence of a 
"A microcode consists of a series of instructions that tell a microprocessor which of its thousands of transistors to actuate in order to perform the [computer's most basic] tasks . . ."53 Microcode is created in the same manner as conventional software with statements written to fulfill each of the necessary functions. ${ }^{54}$ The statements are then used to etch the proper gate configuration onto the microprocessor chip. The Intel microcode, for example, consisted of a pattern of 10,752 tiny transistors with both logic and memory circuits. The court held that microcode fit within the statutory definition of a computer program and was therefore copyrightable. ${ }^{55}$

The microcode can be, and is at one point in its creation, represented as a set of statements. Furthermore, microcode can even be "stored" on a chip in the same manner that conventional software is stored on a PROM. Copyright protection for microcode, therefore, represents no extension of the so-called "firmware doctrine."56 In NEC Corp., Judge Grey was justified in treating the microcode as firmware because NEC decided not to dispute the copyrightability issue.

The Copyright Office has also looked to the form of the work and the method of creation when determining which aspects of computer technology qualify for copyright protection. For example, when registration was initially sought for a PAL, the Copyright Office sought more information on its method of creation. ${ }^{57}$ In response, the applicants submitted a picture of the PAL's wiring and the set of statements used to connect the gates in the desired configuration. The Copyright Office

written set of statements rather than a drawing may have played some role in the courts determination). This seems likely given that Intel's attorneys were arguing similar method of creation for microcode as compared to conventional software, see F. Thomas Dunlap, Jr., NEC v. Intel: A Challenge to the Developing Law of Copyright in the Protection of Computer Programs, 3 SANTA Clara Computer \& High Tech. L.J. 3, 5-6 (1987), and the prior factual finding by Judge Ingram explicitly finding the methods of creation similar. See NEC Corp. v. Intel Corp., 645 F. Supp. 590, 593 (N.D. Cal. 1986) (preliminary findings of fact). These findings were withdrawn when Judge Ingram recused himself by order of December 16, 1987. See NEC Corp. v. Intel Corp., 835 F.2d 1546 (9th Cir. 1988) (dismissing appeal on issue of whether Ingram's stock investment in Intel was sufficient to require recusal). Note that before Judge Grey, NEC did not put on any evidence to show that microcode should not be considered a program or that the chip was not a copy. Interview with Daniel Siegel, Attorney, Ciotti \& Murashige, Irell \& Manella (Mar. 6, 1989).

53. NEC Corp., slip op. at 3; see also Chips Hearings, supra note 16, at 41; Dan Morgan, High Tech: Leaving Home-Battling to Innovate and Emulate: Intel v. Nippon Electric, Wash. Post, May 2, 1983, at Al, col. 1, reprinted in Chips Hearings, supra note 16, at 38, 42; David A. Patterson, Microprogramming, Scr. AM., Mar. 1983, at 50, 50.

54. See Morgan, supra note 53, at AI, col. 1; Robinson, supra note 17, at 200-01.

55. NEC Corp., slip op. at 3-8.

56. The firmware doctrine subsumes two questions: whether the original work is a computer program and whether the chip is a copy of that work. Microcode has the same one-toone correspondence as conventional firmware. Since each line of the original work is stored in memory as a 0 or 1 , it falls within the reach of the firmware doctrine. See Phil Koopman, Microcoded Versus Hard-wired Control, BYTE, Jan. 1987, at 235, 240-42.

57. See Letter from Nancy H. Lawrence, Head Literary I, Examining Division, to Kirk G. Downing (Nov. 23, 1987) (“Is this work a computer program? If so, how is it created?"). 
registered the PAL equations as a computer program on February 25, 1987. Two suits have been filed on the copyright. ${ }^{58}$ One is pending trial under a maintenance preliminary injunction and the other has been dismissed pursuant to a stipulated permanent injunction. ${ }^{59}$ Pending the decision in the remaining case, the Copyright Office has suspended granting registrations for the statements used to program a PLD. ${ }^{60}$

Both the microcode decision and the registration of the PAL "program" are troublesome. The heart of the controversy is not that a form of the work may satisfy the definition of computer program given in section 101 of 17 U.S.C., but rather whether a chip produced using that program is a copy. A material object, such as a chip, is a copy if the work "can be perceived, reproduced, or otherwise communicated, either directly or with the aid of a machine or device."61

Traditional firmware satisfies the copy definition because the exact literal expression of the object code version stored in it can be reproduced. On the other hand, ASICs do not satisfy the definition in the same way because they cannot reproduce the set of equations used to create them. This is the functional difference between memory and logic circuits: Logic processes data, while memory stores it. However, this difference between memory and logic does not justify excluding logic circuits from copyright protection.

\section{Protecting ASICs Through Copyright}

Should the courts extend copyright protection to hardware by reading the definition of "computer program" in section 101 of the Copyright Act to include sets of statements used in the creation of an ASIC?

To answer this question it is necessary to examine whether the logic-memory dichotomy in technology should be applied as a legal

58. See Verified Complaint, Alloy Computer Prods. v. Asadi, No. 87-01285 (C.D. Cal. filed Mar. 23, 1987); Verified Complaint, Alloy Computer Prods. v. Ultratek Corp., No. 8706993 (C.D. Cal. filed Oct. 20, 1987).

59. See Alloy Computer Prods. v. Ultratek Corp., No. 87-06993 (C.D. Cal. Nov. 15, 1987) (order granting preliminary injunction restraining Ultratek from destroying evidence, disclosing any PAL programs, and "transferring any PAL program other than by sale in the ordinary course of business of a Multi-Master board containing a PAL (affixed to it) with the program encoded in it"). Plaintiff sought to prohibit the sale of boards containing the PALs, as well as to seize and impound all unauthorized PAL programs, but the court refused to grant these remedies. Compare Verified Complaint at 5, Alloy Computer Prods. v. Ultratek Corp., No. 87 06993 (C.D. Cal. filed Oct. 20, 1987) (injunctive relief sought), with Order Re Preliminary Injunction at 2, Alloy Computer Prods. v. Ultratek Corp., 1988 Computer Industry Litigation

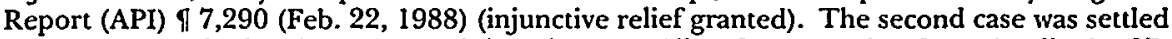
pursuant to a stipulated permanent injunction. See Alloy Computer Prods. v. Asadi, No. 8701285 (C.D. Cal. April 22, 1987) (order granting stipulated permanent injunction). The plaintiff in Ultratek is represented by two large law firms, one in Boston and one in Los Angeles, while the defendant is pro se.

60. Interview with Ronald Laurie, Attorney, Ciotti \& Murashige, Irell \& Manella (Mar. 6, 1989).

61. 17 U.S.C. § 101 (1982). 
standard to exclude ASICs from copyright protection. The examination entails a somewhat detailed exploration of the copyright doctrine of fixation, from which I conclude that the logic-memory dichotomy should not bar copyright protection for logic circuits. Even without a conceptual basis to differentiate hardware from software, some have employed other copyright principles to argue for the exclusion of hardware from copyright, including the useful article limitation, limited rights in depictions of useful articles, and the idea-expression dichotomy, and I deal with each of these in turn.

After concluding that ASICs can be protected under copyright if we want them to be, I proceed to show that, despite the technological nature of ASICs' development, we should want them to be, based on the two principles of copyright, the level of investment and the direction for investment.

Finally, I show that copyright can be applied to a technically oriented work providing extra incentives to its creators without necessarily stifling the production of future works.

\section{A. Disposing of the Conventional Copyright Arguments Against Protecting Chips Within Copyright}

Copyright initially attaches when an original work of authorship is fixed in a tangible medium of expression. ${ }^{62}$

First, the work must be original; however, the originality standard for protection under copyright is very low. Basically, so long as a work is not a copy, it qualifies as original. ${ }^{63}$

Second, the work must be authored. A work of authorship does not require that an author in the colloquial sense write it, but instead requires that the work either fall within one of the seven categories of works protected by copyright or be sufficiently similar to these previously protected works that copyright protection is justified by analogy. ${ }^{64}$

62. 17 U.S.C. \$ 102(a) (1982); see also Copyright REPORT, supra note 1, at 51-52, 1976 U.S. Code Cong. \& Admin. News at 5664-65; 1 P. Goldstein, supra note 4, at \$§ 2.1, 2.4.

63. See, e.g., Hutchinson Tel. Co. v. Frontier Directory Co., 770 F.2d 128 (8th Cir. 1985); Rockford Map Publishers v. Directory Serv. Co. of Colo., 768 F.2d 145, 149 (7th Cir. 1985), cert. denied, 474 U.S. 1061 (1986); Durham Indus. v. Tomy Corp., 630 F.2d 905, 910 (2d Cir. 1980); Schroeder v. William Morrow \& Co., 566 F.2d 3, 5 (7th Cir. 1977); Hartfield v. Peterson, 91 F.2d 998, 999-1000 (2d Cir. 1937); NEC Corp. v. Intel Corp., No. C-84-20799-WPG, slip op. at 4-5 (N.D. Cal. Feb. 6, 1989); Rand McNally v. Fleet Management Sys., 600 F. Supp. 933, 935 (N.D. Ill. 1984); Hubco Data Prods. Corp. v. Management Assistance, 219 U.S.P.Q. (BNA) 450, 453-54 (D. Idaho 1983); National Business Lists v. Dun \& Bradstreet, Inc., 552 F. Supp. 89, 91-95 (N.D. Ill. 1982); Alva Studios v. Winninger, 177 F. Supp. 265, 267 (S.D.N.Y. 1959); see also 1 P. Goldstein, supra note 4 , at $\$ 2.2$.

64. 17 U.S.C. $\S 102$ (a) (1982) (literary works, musical works, dramatic works, pantomimes and choreographic works, pictorial, graphic, and sculptural works, motion pictures and other audiovisual works, and sound recordings). Goldstein refers to the second requirement as expression, but his description of its substance focuses on whether the work in question falls within or is sufficiently similar to one of the seven categories of works listed in the statute. See 1 P. Goldstein, supra note 4, at \$ 2.6. I prefer to use the phrase work of author- 
Finally, for protection to attach, the work must be fixed. It cannot be merely a song in one's head, but must have been set down in a medium, such as written on paper as a musical score or recorded on a tape, where it can be "perceived, reproduced, or otherwise communicated for a period of more than transitory duration." 65

If all three of these requirements are satisfied, the author has the exclusive rights laid out in section 106, including rights to reproduce or sell a copy of the work, or to prepare derivative works from the work, which in turn are limited by the statutory defenses laid out in sections 107-118.66 Anyone who violates one of the exclusive rights provided by sections $106-118$ is guilty of infringement. ${ }^{67}$

1. Aspects of ASIC design qualify for copyright.

To create an ASIC, the designer writes a set of descriptive statements in either Boolean algebra or a simulator's descriptive language. This set of statements is the copyrightable work that we want to focus on rather than the resulting circuits as ultimately formed in silicon.

In considering ASICs, two of the three requirements for protection can be disposed of quickly. We can assume that the work in question is original, that the designer created it in response to some perceived external stimuli without copying from past works. ${ }^{68}$ The designer has fixed the statements by writing them out, initially on paper and later on a keyboard interfaced with some type of electronic memory. ${ }^{69}$

The third requirement, that of a work of authorship, requires a more extended discussion. To avoid the murky area of what might not fall within one of the seven categories, yet remain sufficiently similar to justify protection, I will restrict the discussion to two of the seven categories explicitly mentioned in the copyright statute, literary works and pictorial, graphic and sculptural works. ${ }^{70}$ Once the statements have been used to create a final gate configuration, focusing on the circuits

ship since it is not clear that exclusion under this requirement implies anything about whether the expression is inseparable from or even substantially dictated by the idea of the work, which seems the core of the idea-expression dichotomy. See text accompanying notes 106-112 and 179-211 infra.

65. 17 U.S.C. § 101 (1982); see also 1 P. GoLdsTEIN, supra note 4, at $\$ 2.4$.

66. 17 U.S.C.A. $\$ \S 107-118$ (West 1977 \& Supp. 1989).

67. 17 U.S.C. $\$ 501$ (a) (1982).

68. Of course, if the work in question is not original, then it would not be protected. Within any given class of works, the fact that some are original while others are not does not bar the works as a class from copyright.

69. See Michael Feuer, I'LSI Design Automation: An Introduction (1983), reprinted in Chips Hearings, supra note 16, at 380-82; Freedman, supra note 31, at 224.

70. 17 U.S.C. $\S 101$ (1982). Note that the scope of copyright protection may vary depending upon the category of the work. See, e.g., 17 U.S.C. \& 113(b) (1982). Of particular concern is the exclusion carried over in $\S 113$ (b) for useful aspects of works classified as pictorial, graphic, and sculptural. Id.; see also CopYrIGHT REPORT, supra note 1, at 55, 1976 U.S. CODE CONG. \& ADMIN. News at 5668. "[T]he Committee is seeking to draw as clear a line as possible between copyrightable works of applied art and uncopyrighted works of industrial design." 
themselves might lead one to exclude the circuits as useful articles within the category of pictorial, graphic, and sculptural works. ${ }^{71}$ However, the principal focus should be on the written statements, for which the category of literary works (specifically computer programs) appears most appropriate. ${ }^{72}$ Even without considering the use of the resulting circuits, these written statements satisfy the definition of computer program in section 101 of the Copyright Act. ${ }^{73}$ They are a set of statements written to be used in a computer, a silicon compiler or programming machine, to produce a result, a final gate configuration. ${ }^{74}$

Even if copyright protects the set of statements prior to conversion to electrical circuits, it still must be determined whether the circuits produced based on those statements constitute a copy. If the circuits are considered a copy, then no one can reproduce or distribute them without the permission of the designer who wrote the original set of statements. ${ }^{75}$ If the circuits are not considered a copy, then the copyright in the set of statements in no way protects the circuits.

To be a copy, the circuits must be a material object from which the work can be "perceived, reproduced, or otherwise communicated, either directly or with the aid of a machine or device."76 In interpreting this section, courts have indicated that various types of computer memory chips created using a copyrighted object code version of a software program are copies of the object code version. ${ }^{77}$ Interestingly, most of the courts have determined that the memory chip is a copy based on earlier decisions relating to video games, the expressive elements of which are copyrightable as audiovisual works. ${ }^{78}$

This reliance is troublesome, since the statute requires that the work

71. See text accompanying notes 99-105 infra. The exclusion represents to some extent the language of the Constitution characterizing works as either "writings" or "discoveries." U.S. Const. art. I, § 8, cl. 8.

72. See 17 U.S.C. $\$ 101$ (1982) (defining computer program as a type of literary work); see also Whelan Assocs. v. Jaslow Dental Lab., 797 F.2d 1222, 1234 (3d Cir. 1986), cert. denied, 479 U.S. 1031 (1987); Apple Computer v. Franklin Computer Corp., 714 F.2d 1240, 1249 \& n.7 (3d Cir. 1983), cert. dismissed, 464 U.S. 1033 (1984).

73. 17 U.S.C. $\$ 101$ (1982); see also NEC Corp. v. Intel Corp., No. C-84-20799-WPG, slip op. at 4-5 (N.D. Cal. Feb. 6, 1989); Siegel \& Laurie, supra note 38, at 11-12.

74. "Computer" is not defined in the Copyright Act.

75. Note that only two of the five exclusive rights apply to the copies of the work: the right to reproduce and the right to distribute. 17 U.S.C. \$ $106(1)$, (3) (1982). The other three rights, the rights to prepare derivative works, perform publicly, and display publicly, apply to the work itself. 17 U.S.C. \& 106(2), (4), (5) (1982).

76. 17 U.S.C. $\$ 101$ (1982) (definition of copy); see Copyright RePort, supra note 1, at 52, 1976 U.S. Code Cong. \& Admin. News at 5665.

77. See Apple Computer v. Franklin Computer Corp., 714 F.2d 1240, 1249 (3d Cir. 1983), cert. dismissed, 464 U.S. 1033 (1984); Williams Elecs. v. Artic Int'l, 685 F.2d 870, 876-77 (3d Cir. 1982); Midway Mfg. Co. v. Strohon, 564 F. Supp. 741, $751-52$ (N.D. Ill. 1983); Tandy Corp. v. Personal Micro Computers, 524 F. Supp. 171, 173-75 (N.D. Cal. 1981). But see Data Cash Sys. v. JS\&A Group, Inc., 480 F. Supp. 1063, 1066 n.4 (N.D. IIl. 1979) (the duplication of a ROM would not be actionable under the 1976 Copyright Act), aff'd on other grounds, 628 F.2d 1038, 1040-41 (7th Cir. 1980).

78. See, e.g., Apple Computer, $714 \mathrm{~F} .2 \mathrm{~d}$ at 1249 (relying on Irilliams Elecs., which dealt with the fixation of the program for a video game); see also Irilliams Elecs., 685 F.2d at 876 ("We 
itself be "perceived, reproduced, or otherwise communicated"79 from the copy. Thus, a chip is a copy of an audiovisual work if the chip, together with the necessary interface, can reproduce the particular series of related images and accompanying sounds which constitute the copyrighted audiovisual work. ${ }^{80}$ To determine if the chip is a copy, the court need only look at the resulting video displays. The logic-memory dichotomy plays no role in this determination.

In contrast, a chip is a copy of a computer program only if the particular literal expression of the copyrighted work can be "perceived, reproduced, or otherwise communicated." 81 In the case of memory chips such as PROMs, the literal expression can be reproduced in object code form. The 1's and 0's "stored" in a PROM may be read directly by instructing the PROM to print out its contents or by testing each possible input and determining the resulting output. ${ }^{82}$ Similarly, the original microcode statements may be determined from the circuits themselves since there is a one-to-one correlation between items "stored" in memory and the commands used to create the chip. ${ }^{83}$

Logic circuits present more difficulty because they do not store data, but instead process it. Therefore, the original statements used to create the logic circuits cannot be reproduced from the circuits themselves. A researcher can take a microscope and decipher the circuits, ${ }^{84}$ but it is unclear whether this on-off switch diagram satisfies the statutory definition of a copy. While the circuits represent, in some sense, the set of statements that generated them, the question is whether that representation equates to the reproduction required by the Copyright Act.

Consider a mechanical analogy. A drill press uses a die to determine the patterns it will drill into a wooden block. Treating the drill press and die system as an analog computer, the die would be a set of

have already rejected defendant's similar argument in the context of the copyrights for the audiovisual works.").

79. 17 U.S.C. § 101 (1982).

80. See, e.g., M. Kramer Mfg. Co. v. Andrews, 783 F.2d 421, 441-42 (4th Cir. 1986); see also Midway Mfg. Co., $564 \mathrm{~F}$. Supp. at 747-48 (copyright in audiovisual work only protects aspects of the circuit board necessary to reproduce the work).

81. See Apple Computer, 714 F.2d at 1248-49 (quoting 17 U.S.C. \& 101 (1982)).

82. See Duncan M. Davidson, Protecting Computer Software: A Comprehensive Analysis, 23 Jurimetrics J. 339, 369 (1983); Peter D. Aufrichtig, Copyright Protection for Compuler Programs In Read Only Memory Chips, 32 Copyright L. Symp. (ASCAP) 133, 149 (1986) (student author).

83. See Koopman, supra note 56, at 242; see also 2 E. KLINGMAN, supra note 26, at 136-42.

84. For an example of reverse engineering using a microscope, see Brooktree Corp. v. Advanced Micro Devices, No. 88-1750, slip op. at 9 (S.D. Cal. Dec. 13, 1988) (no infringement under the Semiconductor Chip Protection Act (SCPA)). It is unclear whether the legitimacy of reverse engineering under the SCPA provides any less protection than does the permissible use of ideas under the copyright law. See E.F. Johnson Co. v. Uniden Corp. of America, 623 F. Supp. 1485, 1501 n.17 (D. Minn. 1985) (recognizing that dumping and analyzing code is a traditional industry practice). But see Whelan Assocs. v. Jaslow Dental Lab., 609 F. Supp. 1307, 1321 (E.D. Pa. 1985) ("'TT]o copy a program . . . one would study the method and manner that the computer receives, assembles, calculates, holds, retrieves and communicates data."), aff'd, 797 F.2d 1222 (3d Cir. 1986), cert. denied, 479 U.S. 1031 (1987). 
instructions (the program) used in the drill press (the computer) to generate a result. The die should therefore be protected as a computer program. Even assuming that the die is protected under copyright, whether the drilled wood block should be considered a copy of that program is the analogous question. If, instead of being mechanically controlled, the drill press were controlled by a microprocessor as directed by a conventional software program, whether the drilled wood block is considered a copy of the software program presents a closer analogy. Finally, replace the drill press and wood block with a programming machine and a programmable chip and ask once again if the resulting programmed chip is a copy of the set of statements used to produce it or merely an article of manufacture.

As in the case of computer screen displays, the requirement that a copy be able to reproduce the work would seem to eliminate the possibility that either the screen display or the drilled wood block could be considered a copy of the computer program which together with the appropriate interface creates it. Neither the screen display nor the wood block can reproduce the literal expression of the program which generated them. ${ }^{85}$

Admittedly, in the case of a screen display, a wood block, or a logic circuit, written statements can be created which describe the object. However, these statements will not necessarily duplicate the original literary expression of the work. For example, in the case of a PAL, the Boolean equations describing its logic circuits could be determined by testing all possible inputs and noting the corresponding outputs. ${ }^{86}$ Still, the resulting equations would represent only the most basic logic of the device, ${ }^{87}$ and as is true of the screen display, many possible higher level programming sequences could be written that would generate these same basic equations.

This is because the PAL assembler eliminates redundancy in the logic of the original work, making it impossible to determine the original expression of the higher level programming sequence. ${ }^{88}$

Thus, an ASIC does not satisfy the reproduction aspect necessary to qualify as a copy of the original set of statements. But, before adopting this logic-memory dichotomy as a legal rule, consider the implications of that line as a guide to copyright protection as illustrated by a control sequence mechanism for a computer.

Such a mechanism might consist of all memory circuits (horizontal microcode), all logic circuits (hardwired), or a mixture of memory and logic circuits (vertical microcode). In any of these three systems, the

85. See Manufacturers Technologies v. CAMS, Inc., No. N-85-253, slip op. at 13-15 (D. Conn. Jan. 30, 1989); Digital Communications Assocs. v. Softklone Distrib. Corp., 659 F. Supp. 449, 455-56 (N.D. Ga. 1987).

86. See Freedman, supra note 31, at 228; Siegel \& Laurie, supra note 38, at 12-13.

87. See Freedman, supra note 31, at 228; Siegel \& Laurie, supra note 38, at 12-13.

88. See Freedman, supra note 31, at 228; Siegel \& Laurie, supra note 38, at 12-13. 
circuits receive electrical signals and actuate the appropriate microprocessor transistors in response.

Conceptually, the horizontal microcode will consist of a large table of instructions. When a signal arrives, it actuates one line of microcode. The microcode bits directly actuate the transistors, thus executing the instruction. With a hardwired mechanism, logic circuits implement the instruction. Vertical microcode combines logic circuits and microcode instructions. ${ }^{89}$

The question, then, is whether this technical difference justifies finding a logic control sequence that uses horizontal microcode but not vertical microcode or hardwiring to be protected by copyright. Adopting the dichotomy as a legal rule would mean that one using horizontal microcode would be protected by copyright but that a logic control sequence using vertical microcode would not. This is perhaps the ultimate illustration of the absurdity of the hardware-software line as a legal rule. While a conceptually consistent line can be drawn, it does not make sense in relation to the objectives of the copyright system. All of the factors justifying copyright protection for such a mechanism using horizontal microcode apply equally to one using vertical microcode.

A different approach is required to avoid a rule inconsistent with the purposes of copyright. Reproduction is only one aspect of the statutory definition of a copy; a copy can also exist if the material object can "otherwise communicate[]" 90 the work. Generally, CONTU has recognized that programs in some forms communicate information only to a computer. ${ }^{91}$

In the control sequence mechanism, any of the three circuits can communicate the proper electrical impulse. Considering the principles of copyright, that ability should suffice to justify a finding that a chip is a copy of the original hardware design. As in the case of memory chips and object code, failing to protect the work in this form would undercompensate the author with respect to the societal value of the work by permitting much of the economic value to escape through piracy of the unprotected, but functionally identical, form. ${ }^{92}$

Thus, by conceiving of ASICs as a copy of the set of statements originally used to create them, ASICs can satisfy the three requirements for

89. See Koopman, supra note 56, at 242; see also 2 E. KLINGMAN, supra note 26, at 136-42.

90. 17 U.S.C. $\$ 101$ (1982) (definition of copy).

91. CONTU FinAl REPORT, supra note 45, at 21; see also Apple Computer v. Formula Int'l, 725 F.2d 521, 524-25 (9th Cir. 1984).

92. Courts have focused on this issue in protecting conventional software stored in chips. See Williams Elecs. v. Artic Int'l, 685 F.2d 870, 877 (3d Cir. 1982) ("an unlimited loophole by which infringement of a computer program is limited to copying of the computer program text but not to duplication of a computer program fixed on a silicon chip"); Midway Mfg. Co. v. Strohon, 564 F. Supp. 741, 751-52 (N.D. Ill. 1983); Tandy Corp. v. Personal Micro Computers, 524 F. Supp. 171, 175 (N.D. Cal. 1981). And courts have focused on it in protecting object code. See, e.g., Midway Mfg. Co., 564 F. Supp. at 751 ("To allow protection of the source code version of a program would be pyrrhic indeed if the object code version ... could be freely reproduced without constituting an infringement."). 
copyright protection to attach. The set of statements is the copyrightable work and the ASIC is a copy or medium of fixation for that work. The failure to differentiate between the work (the set of statements) and its copy (the ASIC) has generated several other arguments suggesting potential bases for denying copyright protection for these works. Yet, these arguments have no foundation so long as the focus remains on the work instead of on the medium of fixation.

\section{The three reasons not to protect hardware.}

Without looking for any conceptual basis to distinguish hardware from software, commentators cite three rules of copyright as foreclosing the possibility of copyright protection for hardware: First, copyright protects a useful article only to the extent of its separable, nonutilitarian aspects; ${ }^{93}$ second, copyright in a 2 - or 3-dimensional representation of a useful article does not protect the useful article itself; 94 and finally, copyright protects only the expression of a work-not the ideas or systems that are described in the work. ${ }^{95}$

The first rule cited by commentators is of no concern because the circuits, a useful article, are not the copyrightable work but rather the media in which the copyrightable work is fixed. Indeed, all media in which a copyrightable work might be fixed must necessarily be useful articles. Whether we are dealing with a PROM, tape, or disk that can

93. See, e.g., Poe v. Missing Persons, 745 F.2d 1238, 1242-43 (9th Cir. 1984) (whether swimsuit is a work of art or a useful article (a piece of clothing) determines whether copyright protection attaches); Gay Toys v. Buddy L. Corp., 703 F.2d 970, 973-74 (6th Cir. 1983) (toys are not excluded as useful articles); Fabrica, Inc. v. El Dorado Corp., 697 F.2d 890, 893-94 (9th Cir. 1983) (folder containing carpet samples was a useful article not protected by copyright); Norris Indus. v. I.T.T. Corp., 696 F.2d 918 (11th Cir.) (wire-spoked hubcap was a useful article not protected by copyright), cert. denied, 464 U.S. 818 (1983); Kieselstein-Cord v. Accessories by Pearl, 632 F.2d 989, 993 (2d Cir. 1980) (decorated belt buckle may be protected as it is more like jewelry than a useful article); Eltra Corp. v. Ringer, 579 F.2d 294, 298 (4th Cir. 1978) (typeface is a useful article not protected by copyright); Carol Barnhart, Inc. v. Economy Cover Corp., 594 F. Supp. 364, 370-71 (E.D.N.Y. 1984) (realistic mannequins are useful articles not protected by copyright), aff $d, 773$ F.2d 411 (2d Cir. 1985).

94. See, e.g., Imperial Homes Corp. v. Lamont, 458 F.2d 895, 899 (5th Cir. 1972) (copyright in architectural plans for home does not prevent other from duplicating the home); Demetriades v. Kaufmann, 680 F. Supp. 658, 664-66 (S.D.N.Y. 1988) (same); Muller v. Triborough Bridge Auth., 43 F. Supp. 298, 300 (S.D.N.Y. 1942) (copyright in drawing of a novel bridge approach designed to unsnarl traffic does not prevent someone else from using that approach); Jack Adelman, Inc. v. Sonners \& Gordon, Inc., 112 F. Supp. 187, 188 (S.D.N.Y. 1934) (copyright in drawing of dress could not protect the dress itself from being copied); see also 1 P. Goldstein, supra note 4 , at $\$$ 2.5.3.2.

95. 17 U.S.C. \$ 102(b) (1982). See also Baker v. Selden, 101 U.S. 99, 103 (1879); Continental Casualty Co. v. Beardsley, 253 F.2d 702, 705-06 (2d Cir.), cert. denied, 358 U.S. 816 (1958); Crume v. Pacific Mut. Life Ins. Co., 140 F.2d 182, 184 (7th Cir.), cert. denied, 322 U.S. 755 (1944); Dorsey v. Old Surety Life Ins. Co., 98 F.2d 872, 874 (10th Cir. 1938); Brief English Sys. v. Owen, 48 F.2d 555, 556 (2d Cir.), cert. denied, 283 U.S. 858 (1931); Freedman v. Grolier Enter., 179 U.S.P.Q. (BNA) 476, 478 (S.D.N.Y. 1973); Drugtax, Inc. v. Systems Programming Corp., 147 U.S.P.Q. (BNA) 313, 314 (M.D. Pa. 1965); $c f$. Russell v. Northeastern Publishing Co., 7 F. Supp. 571, 572 (D. Mass. 1934) (copyright in layout and discussion of contract bridge situation covered only the exact language and could not provide an exclusive right in the distribution of the cards or the principles of contract bridge). 
store software programs, film that can store audiovisual works, paper that can store literary works, or a compact disk that can store a sound recording, the medium of fixation is certainly useful, but that does not prevent the work stored therein from achieving copyright protection. ${ }^{96}$ In each case, others are free to use these media to store their own, or other noninfringing, works. ${ }^{97}$ Copyright protection in the work merely prohibits others from reproducing or distributing any medium that contains the author's copyrighted work without the author's consent. ${ }^{98}$

The second rule cited to deny copyright protection to hardware relies to some extent on the method of hardware's creation. This argument points to the differences in appearance between conventional hardware design and source level programming. Conventional hardware design looks like an architectural drawing from which the final gate configuration is built. Source level programming, on the other hand, looks like a new type of poetry, following new rules of rhyme and meter. The argument points to conventional hardware design and indicates that it is a pictorial, graphic, and sculptural depiction of a useful article. While the drawing can be copyrighted, ${ }^{99}$ the argument concludes, that copyright protection in no way reaches the resulting circuits built based on the drawing.

It is conveniently forgotten in reaching this point that both the drawing and source code are representations of useful articles. ${ }^{100}$ They are merely two different languages for designing final gate configurations in a computer. One uses pictures, the other words. Neither produces a result inherently more useful than the other. Rather, each produces an equally useful result-the final gate configuration. Even though final gate configurations are functional, Congress has expressed a clear intention to protect the representations of those configurations through copyright. ${ }^{101}$ Furthermore, ASIC design usually involves words rather than pictures.

96. See Copyright RePORT, supra note 1 , at 55 , reprinted in 1976 U.S. Code Cong. \& Admin. News at 5666; see also Midway Mfg. Co. v. Artic Int'l, 704 F.2d 1009, 1012 (7th Cir.), cerl. denied, 464 U.S. 823 (1983); Williams Elecs. v. Artic Int'l, 685 F.2d 870, 876-77 (3d Cir. 1982); Midway Mfg. Co. v. Strohon, 564 F. Supp. 741, $751-52$ (N.D. Ill. 1983). The definitions of audiovisual works, literary works, and sound recordings in section 101 explicitly state that the works are copyrightable "regardless of the nature of the material objects ... in which they are embodied." 17 U.S.C. $\$ 101$ (1982).

97. See Midway Mfg. Co. v. Artic Int'l, 547 F. Supp. 999, 1008-09 (N.D. Ill. 1982), aff'd, 704 F.2d 1009 (7th Cir.), cert. denied, 464 U.S. 823 (1983). "While the court agrees that utilitarian objects may not be copyrighted, it appears that Artic has misconstrued the copyrights at issue in this case .... Midway no more restricts the use of ROMs than an author with a valid copyright restricts the use of books." Id.

98. 17 U.S.C. $§ 106(1)$, (3) (1982).

99. See Chips Hearings, supra note 16, at 76, 86-88 (statement of Dorothy Schrader).

100. See Harris, supra note 18 , at 191 ; Sprowl, supra note 18 , at $785-87$.

101. CONTU Final REPORT, supra note 45, at 21 ("that the words of a program are used ultimately in the implementation of a process should in no way affect their copyrightability"); see also M. Kramer Mfg. Co. v. Andrews, 783 F.2d 421, 435 (4th Cir. 1986); Apple Computer v. Franklin Computer Corp., 714 F.2d 1240, 1251 (3d Cir. 1983) (citing CONTU), cert. dismissed, 464 U.S. 1033 (1984). 
Note that recognizing the method of creation as the basis for drawing the legal line between hardware and software creates a dichotomy between computer technology and everything else. ${ }^{102}$ If a gate configuration is originally represented in a literal, rather than pictorial form, the gate configuration qualifies as a copy of the original representation. A mere change in form changes the resulting protection. Yet, changing from a pictorial to a literal representation of a useful article outside the computer arena would not make the useful article a copy of the literal representation of it.

For example, if one were to write out the design for a house, instead of drawing up the design as architectural plans, the house would still not qualify as a copy of the copyrightable literary work. ${ }^{103}$ Even though the literary work can be reproduced from the house, as surely as the program can be reproduced from the resulting logic circuits, that is not sufficient for the house to qualify as a copy of the writing. The crucial difference is that the house, unlike the circuits, cannot otherwise communicate the literary work.

Thus, Congress's decision to protect computer programs as a form of literary work rather than as a pictorial, graphic, or sculptural work necessitates that a line be drawn between useful aspects of computers and other useful articles. This raises the question of whether the harder line to draw is between hardware and software, or between computers and everything else. ${ }^{104}$ The justifications for this dichotomy lie in the nature of computer technology and in Congress's perception that computer technology requires copyright protection to safeguard the proper level of, and direction for, investments. Apparently, theft in other areas of industrial design is either not sufficiently rampant or not sufficiently harmful to persuade Congress to provide copyright protection. ${ }^{105}$

The third and final argument made against extending copyright protection to hardware is that the set of statements defining the gate configurations in logic circuits is either an idea, system, or process. Therefore, in accordance with section 102(b), the gate configuration statements cannot be protected. Various design constraints require

102. Furthermore, if protection is extended to the resulting works in different fashions depending on whether they look like a diagram or a poem, to the extent that the protection from looking like a poem is valuable, hardware designers will just be encouraged to adopt a new language for their work or at least appear to have adopted one. The process and results will still be the same, but at one point the work will look like traditional source code.

103. To reach this result, a court would hold that the house is not a copy of the literal work and would not rely on the limitation in $\$ 113$ that applies only to pictorial, graphic, and sculptural works. See 17 U.S.C. \$ 113 (b) (1982).

104. This is especially so if one adopts the notion that the world itself is actually a giant computer designed to determine the meaning of life. See Douglas Adams, So Long, ANd ThaNkS FOR ALL THE Fish (1985).

105. Note the adoption of an industrial or design copyright for mask works, while the general design copyright legislation floundered. See Chips Hearings, supra note 16, at 121, 169 71 (testimony of Dorothy Schrader). 
certain elements in the set of statements. These elements would be unprotected because their value is a function of factors external to the creativity of the author. ${ }^{106}$ Yet, something more is argued here: Some commentators maintain that the set of statements is itself an idea, system, or process and that therefore no part of the set of statements should be protected. ${ }^{107}$

Fortunately for our purposes, the exact scope of the statutory exclusion of aspects of otherwise copyrightable works contained in section 102(b) need not be explored. All we must recognize is that the section 102(b) exclusion is not self-defining. Ultimately, it consists of those things that the courts find to be not protected by copyright.

For example, in the landmark copyright case of Baker $v$. Selden, 108 the Court was presented with a question of copyright infringement pertaining to a copyrighted work book that laid out a new method of bookkeeping. The book also contained blank forms that were necessary to use this approach to bookkeeping. The alleged infringer had written a competing book that detailed, in a somewhat different fashion, the same method and contained copies of the same blank forms. ${ }^{109}$ In finding the second work did not infringe the first, the Court held that the copyright in the book, while still valid, protected neither the new method nor the blank forms necessary to use the method.110 Thus began the category of aspects of works not protected by copyright, which is now reflected in section $102(\mathrm{~b})$.

In focusing on whether the statements used to create an ASIC should be found to be excluded from copyright protection by section 102(b), the analogy to conventional software significantly undermines the exclusion argument. The set of statements that are used to create

106. See, e.g., Plains Cotton Coop. v. Goodpasture Computer Serv., 807 F.2d 1256, 1262 (5th Cir.), cert. denied, 108 S. Ct. 80 (1987); Wickham v. Knoxville Int'l Energy Exposition, 739 F.2d 1094 (6th Cir. 1984); NEC Corp. v. Intel Corp., No. C-84-20799-WPG, slip op. at 34 (N.D. Cal. Feb. 6, 1989); Q-CO Indus., Inc. v. Hoffman, 625 F. Supp. 608, 616 (S.D.N.Y. 1985); E.F. Johnson Co. v. Uniden Corp. of America, 623 F. Supp. 1485, 1500-02 (D. Minn. 1985). But see Pearl Sys. v. Competition Elec., 8 U.S.P.Q.2d (BNA) 1520 (S.D. Fla. 1988) (copyright in program protects the configuration of the device's external controls to the extent that other equally useful configurations are available; sort of like the tail wagging the $\operatorname{dog})$.

107. See Hinckley, supra note 12, at 34 ("Accordingly, because microcode is effectively inseparable from the microprocessor itself, the sensible approach in determining the legal protection to be afforded microcode is to decide on the proper form of protection for the microprocessor as a whole . . " and that is not copyright.); Friedman, supra note 12, at 298; Samuelson, supra note 12, at 741. A number of courts have considered and rejected the argument. See Apple Computer v. Formula Int'l, 725 F.2d 521, 523 (9th Cir. 1984) ("Formula contends that the computer programs involved in this lawsuit, because they control the internal operation of the computer, are only 'ideas' or 'processes' . . . ."); Apple Computer v. Franklin Computer Corp., 714 F.2d 1240, 1250 (3d Cir. 1983) ("Franklin argues that an operating system program is either a 'process,' 'system,' or 'method of operation' and hence uncopyrightable." (citation omitted)), cert. dismissed, 464 U.S. 1033 (1984); NEC Corp., slip op. at 5-6 (rejecting that microcode is necessarily a system).

108. 101 U.S. 99 (1879).

109. Id. at $100-01$.

110. Id. at 104-05. 
an ASIC are no more a system than are the analogous set of statements protected under copyright as conventional software. Both are merely a person's attempt to solve a particular problem. In some circumstances, two people may be trying to solve the same problem, one through circuit design and one through software design. ${ }^{111}$

Both sets of statements respond to the constraints imposed by the medium in which the designers are working. The difference is that circuit design takes place in a realm bounded more directly by the electrical laws of nature than software design, which takes place in a realm where conventions are superimposed over the electrical laws of nature. Yet, this difference does not render the set of statements associated with traditional techniques of hardware design an idea. Certainly, copyright will not provide an exclusive right to exploit the laws of nature. But protecting a set of statements reflecting those laws, which is used to create an ASIC, provides no more monopoly over the laws of nature than does the protection of conventional software or conventional literary works over their respective constraints. ${ }^{112}$

Thus, given that software programs stored in memory chips are protected under copyright, the formal copyright structure does not justify excluding from protection a set of statements used to create the circuits of an ASIC. Of course, the structure merely reflects the underlying principles that copyright ideally serves. Those principles call for protecting both the original set of statements and the resulting copy (the ASIC) under copyright.

\section{B. The Two Principles Underlying Copyright}

Two principles should control the type of protection afforded to the various elements of computer technology: ensuring that the balance is struck at the socially optimal level between the incentives to produce and the free flow of ideas, and ensuring that the system of protection does not establish the direction of investment (i.e., that one design worth $\$ 3$ million to society receives $\$ 1$ million in incentives while a second design worth the same receives no incentives).

\section{The necessary level of incentives.}

In looking at the balance between the author and society as it applies to ASICs, we must address the questions of whether a legal monopoly is necessary to produce the correct level of investment and

111. See, e.g., Koopman, supra note 56, at 235 (comparing instruction decoding and execution control sections for a computer: one using microcode, the other, hardwired logic); see also Harris, supra note 18 , at 209-10.

112. For example, copyrighting a program in BASIC that was written for a particular microcomputer creates a monopoly only over that particular expression, not over the BASIC language or the microcomputer. Similarly, the protection of a conventional literary work creates no monopoly over the use of paper and ink or grammatical rules. 
whether the functional character of ASICs indicates that some other legal system would better provide that protection.

An important preliminary issue to resolve is whether copyright protection for the set of statements defining a gate configuration will in any way affect the cost to the consumers, or if the existing incentives given to all aspects of computer technology instead will be redistributed to give designers working in this aspect of computer technology a larger share.

For example, providing performers a performance right in sound recordings would be unlikely to increase licensing revenues to BMI or ASCAP, since bars and radio stations are unlikely to pay more for what appears to them to be the same right, playing the records. Instead, such a grant would redistribute the fees paid to ASCAP or BMI between existing rights holders and the new rights holder, the performers. ${ }^{113}$ Similarly, the added protection of copyright is unlikely to enable the producer of chips already covered by patent to charge a higher price for its products. ${ }^{114}$ For these chips, copyright may only redistribute some of the value of the work from the chip manufacturer to the designer. ${ }^{115}$

Generally ASICs will not satisfy the high standards necessary to obtain patent protection. Therefore, copyright protection may signifcantly increase the incentives associated with producing them as compared to a market where they are not protected by copyright. An increase in incentives is likely because of the "public good" nature of these works.

Traditional public goods are products for which the benefits are too dispersed to provide an adequate incentive to produce privately. ${ }^{116}$ Examples include national defense, maintenance of law and order, lighthouses, and public gardens. Government generally must provide these goods, because their benefits are widely dispersed among a variety of users, and because their economic value is either uncertain (as in the case of national defense) or difficult to measure in economic terms (as in the case of beautiful public gardens).

Computer technology contains some aspect of the public-good market failure in that the works cost far less to copy than to create. ${ }^{117}$ Un-

113. Interview with Professor Paul Goldstein, Stanford Law School (Feb. 15, 1989).

114. Generally, patent protection would be available for those gate configurations that represented a substantial advance over the prior art, such as the Intel 80386 chip, see Kathleen K. Wiegner, I'tho's on Second?, Forbes, Mar. 7, 1988, at 158, 158-60, or IBM's Micro Channel architecture, see Mike Seither, Chips Fall into Place for IBM PS/2 Compatibles, Mrni-Mrcro SYs., Mar. 1988, at 12, 12-20.

115. If the designer is an employee of the chip manufacturer, then any copyright would vest initially in the manufacturer under the work-for-hire doctrine. See 17 U.S.C. $\$ 201$ (b) (1982); see also Community for Creative Non-Violence v. Reid, 109 S. Ct. 2166,2171 (1989).

116. See, e.g., Paul A. Samuelson \& William D. Nordhaus, Economics $48-49$ (12th ed. 1985).

117. See Peter S. Menell, Tailoring Legal Protection for Computer Software, 39 Stan. L. Rev. 1329,1337 (1987). Note that programs are not truly characterized by nonrivalrous consump- 
less some protection against copying is provided, a copier, with no investment in the original development of the work, can charge such a low price for his copied product that the original author cannot earn a reasonable return on his investment in creating the work. ${ }^{118}$ This does not mean that these works will go unproduced. 119 The economic benefit may be sufficient for a company to hire a designer to create such a work even in the absence of copyright protection. ${ }^{120}$ Rather, it indicates that the level of incentives will be lower than, and the direction of investment different from, that prevailing in a market where the return is a function of the societal value of the work. ${ }^{121}$

In the current market for ASICs, the work's economic benefit plays a primary role, while the public-good aspects remain secondary. Just as the investment in early software was recouped as part of the price of the hardware on which it ran, ${ }^{122}$ much of the investment in ASICs can be recouped through contract in the absence of copyright protection, because the works are largely produced under special order arrangements. ${ }^{123}$ As a result, investment capital to develop this kind of computer technology has been readily available. ${ }^{124}$

As technological advances provide a more general and interchangeable role for ASICs, and as ASICs become an equivalent to today's mass-marketed applications software for personal computers, the mar-

tion. Even with games, being the only kid on the block to possess a copy may have some value. As programs get more involved, consumption becomes more rivalrous. Thus, two engineering firms competing against one another for design work are not likely to share freely their computer-aided design programs with one another.

118. See Yale Braunstein, Economics of Properly Rights as Applied to Computer Softuare and Data Bases, in 4 Copyright, Congress and Technology: The Public Record 2, 53-56 (N. Henry ed. 1980); Semiconductor Industry Ass'N, The Economic Effects of Chip Piracy ON THE U.S. SEMICONDUCTOR INDUSTRY (1983), reprinted in Chips Hearings, supra note 16, at 179, 180 [hereinafter SEMIConductor Industry Ass'N].

119. See Stephen Breyer, The Lineasy Case for Copyright: A Study of Copyright in Books, Photocopies, and Computer Programs, 84 HaRv. L. Rev. 281, 291-306 (1970); John P. Palmer, Copyright and Computer Softwate, in Research in LAw and Economics: The Economics of PATENTS AND Copyrights 205, 212-13 (J. Palmer \& R. Zerbe eds. 1986).

120. For extmple, consider a law firm where the billing is done manually. The law firm calculates that replacing the manual system with an automated system will reduce costs and improve receipts. The economic benefit from having the automated system is less than the cost of the equipment required plus the cost to hire someone to program the system. Therefore, the law firm will likely buy the equipment and hire the programmer, despite the absence of any copyright protection in the resulting program.

121. See Braunstein, supra note 118, at 52-62; SEmiconductor Industry Ass'N, supra note 118 , at $180-86$.

122. Organisation for Economic Co-operation and Development, Software: An EMERging Industry 55 (1985). Beginning in 1969, the Justice Department required IBM to invoice hardware and software separately, eliminating IBM's tying arrangement. Id. at 55-56.

123. See Simpson, supra note 17 , at 122 (69\% of semicustom chips were designed by customers using the vendors' equipment, $15 \%$ were designed by the vendors, $10 \%$ were designed by customers using their own equipment, and $6 \%$ were designed by distributors or independent consultants).

124. See Rice, supra note 17 , at 30 (" "The venture capitalists were in a frenzy because now you could sell product that would be priced for its value.' ") (quoting Wes Patterson, Marketing Vice President of Xilinx). 
ket can be expected to shift to the point where these informal mechanisms of protection are inadequate. ${ }^{125}$ Recent increases in competition, with resulting decreases in prices and rates of return, along with the inclusion of these works in goods marketed publicly, indicate that this point either already has been reached, or soon will be. ${ }^{126}$ Along with this shift in the market should come a recognition that copyright is as necessary to protect these works as it was to protect conventional software and chip masks. ${ }^{127}$

Since ASICs can be found in many broadly marketed products, competitors can appropriate much of the future value of the work. For example, several personal computers marketed recently have contained PLDs. ${ }^{128}$ The societal value of these works is the sum of their present value, which represents the value of the intellectual creativity incorporated into the product (largely recovered through the initial design contract), and their future value, which represents the ability to incorporate this same intellectual creativity into making improvements or creating other works. If the circuits are not protected by copyright as a copy of the original set of statements, a competitor will be free to incorporate them into future improvements, thereby depriving the original author of a significant portion of the work's societal value.

This qualitative analysis of the economic factors involved in hardware design indicates that market mechanisms will undercompensate investment in such design. Quantitative factors in the marketplace itself support this qualitative analysis, indicating that the present system of rights provides inadequate incentives to investment in hardware design as compared to a market where the return on investment reflects the societal value of the work. Three prominent factors deserve discussion: the shortage of skilled personnel, the slowing of capital formation as a percentage of output, and the decreased investment in research. Though these factors are only partially a result of the public-good nature of these works, they confirm the qualitative economic analysis and

125. This point is reached when the revenues from the first sale no longer provide sufficient incentives to create the work. On the evolution of PLDs, see Cole, supra note 30, at 6163.

126. See Rice, supra note 17 , at $30-31$.

127. Protecting software under copyright has been criticized repeatedly. See Karjala, supra note 18; Pamela Samuelson, Creating a New Kind of Intellectual Properly: Applying the Lessons of the Chip Law to Computer Programs, 70 MinN. L. REv. 471 (1985); Samuelson, supra note 12; Peter G. Spivack, Does Form Follow Function? The Idea/Expression Dichotomy in Copyright Protection of Computer Software, 35 UCLA L. REv. 723 (1988) (student author). Despite these criticisms, copyright's originality standard, rather than patent's novel and nonobvious standard, has been generally accepted as a better reflection of the level of creativity deserving of protection in the case of computer technology. This notion was behind the SCPA. See Chips Hearings, supra note 16, at 75 (testimony of Gerald J. Mossinghoff, Assistant Secretary of Commerce and Commissioner of Patents and Trademarks) ("[T]here is almost unanimous agreement that the kind of protection [for chips] should be registration-type, copyright-like protection rather than patent-like protection.").

128. See Birkner, supra note 15, at 208 (PAL chips designed into Data General's MV8000 computer, Apple's Macintosh, and PC-clone expansion boards). 
provide objective evidence of a need for greater incentives for investment in circuit design.

The current shortage of chip designers and engineers suggests that protection is inadequate. ${ }^{129}$ In this context, shortages indicate that firms would hire additional engineers or designers, if any were available at current salary levels. Though increasing current salaries would help to eliminate the shortage, to the extent that economic returns enter into career path decisions, ${ }^{130}$ under the current level of incentives firms are unable to raise salaries and also satisfy rate of return expectations. ${ }^{131}$

This suggests that the current level of incentives is inadequate to provide the goods desired by the public - that is, the demand for qualified designers exceeds the supply. In the absence of the public-good nature of the resulting product, prices should rise until supply and demand equalize. Since copying of the unprotected design by competitors prevents this, an increase in protection can be justified to the extent that an increase in returns on these investments would raise the level of compensation paid the designers. ${ }^{132}$ As long as firms reinvested the extra returns in this field, demand for these employees likely would increase, indirectly achieving the same effect.

129. See Organisation for Economic Co-operation and Development, supra note 122, at 131-32; Robert Eckelmann, A Study of the Competitive Position of the U.S. Computer Industry, in The Fl'T'Re of the Semiconductor Computer Robotics and Telecommunications INd'sTRIES 37, 69, 75 (1984); Robert N. Noyce, Semiconductor Industry Overview, in ThE Fl'Tl'RE OF THE Semiconductor Computer Robotics and Telecommunications INDistries, supra, at 11, 13 ("Japan is producing, on a per capita basis, nearly four times as many electrical engineers as is America."); Robinson, supra note 17, at 197.

130. See, e.g., Greed Gains Ground, U.S. News \& World ReP., Jan. 25, 1988, at 10 ("More than three quarters of college freshmen now think that getting rich is what life is all about ....") (quoting a survey by the American Council on Education). See generally Carnegie Foundation for the Advancement of Teaching, Academe and the Boom in Business Studies, Change, Sept./Oct. 1988, at 37.

131. If a firm can raise salaries, thereby increasing its work output, and still satisfy rate of return requirements, it would be economically foolish not to do so. See, e.g., STEPHEN A. Ross \& Randolph W. Westerfield, Corporate Finance 62 (1988) ("An investment is worth making if it has a positive [net present value].").

132. Several factors distort this analysis. For example, there may be extraneous factors limiting an individual's ability to pursue an education in chip design, such as a poor math education at the precollege level. Also, the incentives may be currently adequate, but a long lead time exists between development of the incentives and the production of qualified personnel. In addition, the directions created by the traditional employee work for hire rule, 17 U.S.C. $\S \S 101,201$ (b) (1982) (favoring capital over investment), may encourage skilled designers to forsake design and enter management in the search for greater economic returns on their labor. See Are You Better Off Now?, Fontune, Oct. 10, 1988 (cover) (scientist: $\$ 46,300$; machinist: $\$ 48,000$; manager: $\$ 74,500$; financial consultant: $\$ 100,000+$ ). Even within the computer technology field, managers earn more than the designers. See What Are You Worth in 1988, Datamation, Oct. 1, 1988, at 53, 58 (average salary for managers: \$49,952; average salary for lead designers: $\$ 45,016$-based on salaries for Systems Analysis, Applications Programming, Systems Analysis/Programming, and Operating Systems Programming). This difference in remuneration is reflected in the number of degrees awarded in the two fields: $23 \%$ of the bachelor's degrees awarded in 1984-1985 were in Business and Management, compared to only $7.9 \%$ in Engineering. Carnegie Foundation for the Advancement of Teaching, supra note 130 , at 38 . 
The lower level of capital formation in hardware design in the United States also indicates a need for greater protection. The semiconductor industry in the United States has spent approximately 17 percent of sales on capital equipment. In comparison, industry in Japan spends approximately 23 percent, and in Europe, approximately 18 percent. ${ }^{133}$ Interestingly, both Japan and Europe have broader industrial design protection for useful articles than does the United States. ${ }^{134}$ Because capital investment determines the level of manufacturing technology, three-quarters of the chip manufacturing plants in Japan can turn out chips with circuit lines smaller than two microns, ${ }^{135}$ whereas only half of the plants in the United States can do so. ${ }^{136}$

The failure of industry in the United States to maintain a competitive research and development growth rate also suggests that returns on investment in hardware design are inadequate. Between 1970 and 1985, research and development expenditures have increased by 190 percent in Japan, by 71 percent in West Germany, France, and the United Kingdom, and by only 55 percent in the United States. ${ }^{137}$ Japan spent 2.77 percent of its gross national product on research and development in 1985 compared to only 1.85 percent in 1970 (an increase of 50 percent). The United States spent 2.69 percent of its gross national product on research and development in 1985 and 2.57 percent in 1970 (an increase of only 5 percent). ${ }^{138}$ France, West Germany, and the United Kingdom increased spending on research and development as a percent of gross national product from 1.91 percent to 2.31 percent (an increase of 21 percent), 2.06 percent to 2.67 percent (an increase of 30 percent), and 2.07 percent to 2.42 percent (an increase of 17 percent), respectively. ${ }^{139}$

Finally, each of these three factors creates its own vicious cycle. A shortage in trained personnel tends to deplete the ranks of educators in the field, thereby inhibiting the training of future personnel. ${ }^{140} \mathrm{~A}$ failure now to invest in equipment and research reduces our ability to compete in the future, with a resulting reduction in income. Assuming a constant relative investment in equipment and research, reductions in

133. Erich Bloch, Critical Factors Facing the Semiconductor Industry in the Turbulent 1980's, in American Prosperity and Productivity 29, 31-32 (1981); see also Valerie Rice, U.S. Chip Makers IVince as Their Wafer Fabs Bulge at the Seams, Electronic BuS., July 1, 1988, at 16, 17; IVill IC and Discrete Makers Finally Loosen the Purse Strings This Year?, Electronic News, Supp. at 5, Mar. 9, 1987.

134. See generally Teruo Doi, The Intellectual Property Law of Japan (1980); Christine Feliner, The future of Legal Protection for Industrial Design (1985).

135. A micron is a thousandth of a millimeter.

136. See Richard Brandt, This Time, The Cycle Won't Be Quite So Vicious for Chipmakers, Bus. WK., Jan. 9, 1989, at 95. 235.

137. See National Science Board, Science and Engineering Indicators-1987, at

138. Id. at 236.

139. Id.

140. See Noyce, supra note 129 , at 13 . 
income spell a reduction in the absolute level of capital equipment and research and development investments. The result has been dramatic: Japan has captured 90 percent of the market for dynamic random access memory chips (DRAMs) and 50 percent of the world market for integrated circuits. The United States controls less than 10 percent and 38 percent of these markets, respectively. ${ }^{141}$

Thus, both qualitative analysis and quantitative reality reveal the need for copyright protection of ASICs. The quantitative indications of market failure also highlight the inadequacies of both trade secret and patent protection for these works, because the failures arose during a time frame when both of these forms of protection were available. ${ }^{142}$ Despite the quantitative evidence to the contrary, some commentators maintain that copyright provides an inappropriate balance between the author and society in the case of useful articles, citing the limitation in section 113(b) concerning the scope of copyright protection for pictorial, graphic, and sculptural works which portray useful articles. ${ }^{143}$ Yet Congress has clearly indicated that copyright protection is appropriate for useful articles in the field of computer technology. ${ }^{144}$

To the extent the inclusion of useful aspects of computer technology under copyright represents a shift from the historic treatment of useful articles, the shift recognizes that computer technology requires a dual system of federal intellectual property protection. Advances in computer technology that satisfy patent's higher standards of novelty and nonobviousness require the broader "substantial equivalent" monopoly of patent. Those works that satisfy the lower originality standard of copyright merit only the more narrow "copying" monopoly of copyright. While commentators may complain that this blurs the line between patent and copyright, ${ }^{145}$ their argument is misplaced. The line between patent and copyright remains firm. But for computer technology, the focus has moved to the level of creativity in the work and the resulting scope of monopoly, rather than whether a particular form of the work is a useful article.

Thus, the balance of incentives provides support for protecting hardware designs as computer programs under the Copyright Act. A more clear-cut justification lies ahead, though, that centers around directions in investment that an intellectual property system can gener-

141. See Brandt, supra note 136 , at 95.

142. This confirms the assumption above that patent, trade secret, and the SCPA would provide inadequate protection for these works. See note 16 supra.

143. See, e.g., Samuelson, supra note 12, at 741; James Chesser, Semiconductor Chip Protection: Changing Roles for Copyright and Competition, 71 VA. L. REv. 249, 275-78 (1985) (student author); Friedman, supra note 12, at 298-99.

144. Both conventional software and chip mask works are protected under a copyrighttype system despite their useful nature. See 17 U.S.C. $\$ \$ 101,117$ (1987) (indirectly including computer programs within the "literary work" category of copyrightable works); 17 U.S.C.A. $\$ \S 901-914$ (West Supp. 1989) (protecting mask works under copyright-like scheme).

145. See, e.g., Chesser, supra note 143, at 276-77; Friedman, supra note 12, at 299 n.128. 
ate, which are contrary to the direction indicated by the value of the resulting work to society.

\section{The appropriate direction of incentives.}

Consider two works that are functionally equivalent and of the same value to society. Providing protection which increases the returns from one, but not the other, will generate a preference to invest in the work receiving protection. Even if the unprotected work is more valuable to society, to the extent the protection enables a firm to receive a greater return, firms will underinvest in the unprotected work and overinvest in the protected work. ${ }^{146}$

The instruction decoding and executing control sections of a modern computer provide a good example. ${ }^{147}$ A firm may, among other options, use either a form of microcode or hardwired logic to accomplish the necessary function. Generally, the advantages of microcode are that it is less expensive to design initially and retains flexibility. The hardwired logic performs the task more quickly. Assume that neither would satisfy the patent standards of novelty or nonobviousness. Both would qualify for copyright under the originality standard, though. Assume further that a copyright enables the holder to recover 3 percent of the value of the work to society, while without copyright protection, only 2 percent can be recovered. ${ }^{148}$ Both cost the same to produce and both are valued equally by society.

If the microcode is protected by copyright and the hardwired logic is not, a firm will choose to invest in the microcode. Even if society preferred the hardwired logic, the firm would continue to invest in microcode until the returns from the two were equal. Thus, given the recovery rates specified above, a firm would not invest in the hardwired logic until society valued the hardwired logic at least 50 percent more than it valued the microcode.

Any lines drawn in this area would create such a directional effect, so long as copyright protection would apply on one side of the line and no formal protection would apply on the other. Whether the line were based on the logic-memory distinction or some conceptually nondistinct line between hardware and software, a firm would, at the margins,

146. Generally, a firm should invest in the area providing the greatest return. See Franco Modigliani \& Merton H. Miller, The Cost of Capital, Corporation Finance and the Theory of Investment, 48 AM. ECON. REv. 261, 288 (1958). Even if managers decide formally on the basis of net present value, there remains considerable leeway in determining expected markets and prices, which a manager can manipulate to obtain the desired answer. But, so long as there is no systematic tendency to invest in the unprotected work despite an expectation of a lower level of return, the level of incentives should control the level of investment. This should occur even if individual projects do not fully reflect an economic choice.

147. See also text accompanying note 89 supra.

148. The absolute value of the returns selected is unimportant. The critical factor is the percent difference between the two. Given that 100 to 1 is a typical ratio of creation to copying cost in this field, the decrease in return without protection is, if anything, conservative. See Chips Hearings, supra note 16, at 71 (testimony of Gerald J. Mossinghoff). 
invest in a work of lower value to society because of the incentives provided by the copyright system. Given the lack of availability of other types of protection, ${ }^{149}$ and the ease with which the intellectual labor can be appropriated, the margins may cover a fairly large area.

The numeric evidence from the market tends to support this common sense notion. Compare, for example, the returns on assets and sales of four companies involved primarily in semiconductor chips with three companies involved primarily in packaged software.

\section{TABLE 1}

COMPARISON OF RETURNS FOR INVESTMENTS IN SOFTWARE Versus SEMICONDUCTOR CHIPS ${ }^{150}$

$\begin{array}{lcc}\text { Returns }(\%) & \text { Software } & \text { Chips } \\ \text { On Assets } & 24.4 & 6.3 \\ \text { On Revenue } & 18.6 & 4.0\end{array}$

The number of degrees awarded in the two fields also provides some indication of the greater returns to be found in software development. For the 1984-85 academic year, 38,878 bachelor's degrees (4 percent of total number awarded) and 7,101 master's degrees (2.5 percent of total) were awarded in computer science as compared to 21,691 bachelor's (2.2 percent of total) and 5,153 master's degrees (1.8 percent of total) in electrical engineering. ${ }^{151}$

While other factors may account for these differences, the differences in returns and in degrees awarded provide circumstantial evidence that providing differing levels of legal protection for functionally equivalent works facing similar markets and requiring similar investments may generate directions of investment contrary to those that would prevail on a level playing field. Thus, to the extent that copyright is the chosen form of protection for conventional software, copyright protection should also be extended to the other symbolic representation of gate configurations-hardware design. Concerns about the balance between the free flow of ideas and the incentives to

149. See note 16 supra.

150. The four semiconductor companies are National Semiconductor, Texas Instruments, Motorola, and Intel. The three software companies are Microsoft, Lotus Development, and Ashton-Tate. The data represent results from the 1987 fiscal year. See Parker Hodges, Charling the Champs, Datamation, June 15, 1988, at 14, 30-33; see also International Trade administration, United States Department of Commerce, A Competitive Assessment of the U.S. Software Industry 13 (1984) (the mean profit margins for a sample of packaged software firms were $19.6 \%$ in 1982 and $22.9 \%$ in 1983); The Electronic Business 200, ELECTRONIC Bus., July 15, 1986, at 86, 110 (the average profit margin for twelve semiconductor companies in 1985 was less than 1.0\%); $R E D D$ Scoreboard, BUS. WK., June 20,1988, at $141,148,158$ (1987 profits as a percentage of sales for semiconductor firms was $4.44 \%$, and for software firms, it was $7.56 \%$ ); The Electronic Business 200, Electronic Bus., July 15, 1988, at 24, 56, 58 (1987 profits as a percentage of sales for semiconductor firms$3.9 \%$; software firms-12.2\%).

151. See Carnegie Foundation for the Advancement of Teaching, supra note 130, at 38. 
produce should be addressed by properly applying the principles of copyright, not by denying protection altogether.

\section{Application of Copyright Principles to Reflect the Proper Balance in the Case of Gate Configurations}

To ensure the proper balance between the free flow of ideas and the incentives to produce, copyright protection must be measured to fit the needs of the work at hand. Some chips can create market externalities that must be considered in determining the proper scope of protection. Just as with music, fabric, literary works, maps, and indeed as with all works protected by copyright, the protection must be tailored to avoid granting a monopoly excessive in scope-a monopoly that is so broad that it rewards the author for societal value she did not create.

\section{Market externalities.}

A chip can create market externalities by establishing a market standard from which individuals are reluctant to switch because of retraining costs entailed in such a switch. ${ }^{152}$ Combining this externality with the advantages of market power leads to our first two theoretical concerns: inferior standard adoption and market monopolization. A third theoretical concern is that copyright protection may impede the development of future works.

As an example, consider a microprocessor that is created by a major chip manufacturer and included within the most popular type of personal computer. Because of the market power of the manufacturer, a large number of consumers purchase the unit, buy software for it, and learn to use it. Having made a substantial time investment to learn the standards associated with one product, the value of a noncompatible model would have to be sufficiently higher to cover retraining costs before consumers would switch. In addition, even if the noncompatible product were substantially superior, if software manufacturers fail to produce software for the new product, very few consumers will buy the product, and it will not recover an appropriate share of its societal value. ${ }^{153}$

This example implicates the first two theoretical concerns. Market monopolization may occur if other manufacturers are not able to compete by marketing compatible computers because of the intellectual property protection on the original. An inferior standard may be adopted or retained as consumers will not want to retrain. Yet the actual data from the marketplace indicates that copyright protection for

152. Cf. Synercom Technology v. University Computing Co., 462 F. Supp. 1003, 1013 (N.D. Tex. 1978) ("Use of the same ["figure-H'] pattern [in all automobiles with manual transmissions] might be socially desirable, as it would reduce the retraining of drivers.").

153. See, e.g., Geoff Lewis, Commodore is Anything but Dead, Bus. WK., Mar. 9, 1987, at 96, 96-97 (detailing difficulties in marketing the Amiga personal computer despite its superior capabilities); see also Karjala, supra note 18, at 46-47; Menell, supra note 117, at 1360-62. 
hardware designs would not exacerbate the extent to which these two theoretical concerns are a marketplace reality.

While a firm with significant market power sometimes can set the standards, market power will exist and influence the market regardless of the presence of either copyright or patent. Data from the actual market for computer technology provide little indication that either copyright or patent protection significantly increases barriers to competition. ${ }^{154}$ Consider the case of the copyright on IBM's basic input-output system (BIOS) on its personal computer. Despite IBM's copyrights in the program, competitors have developed their own versions of functionally equivalent BIOS. ${ }^{155}$ Since creating a functionally identical version does not infringe the copyright-only copying IBM's version would do that-the copyright on the program has not signifcantly limited competition among IBM-compatible personal computers.

Even the broader protection of patent provides no guarantee of exclusivity when it comes to computer technology. IBM patented its Micro Channel architecture in its new PS/2 line of personal computers. Already, several manufacturers have come out with sets of chips that duplicate the functions of the IBM standard. ${ }^{156}$

A copyright or a patent will provide the owner with either additional lead time or additional licensing fees. If the competitor cannot obtain a license, she may have to "reinvent the wheel" and come up with a different way of accomplishing the same result. This is not necessarily bad, though. To the extent the extra incentive provided by the lead time or license fees encourages creation of the works in the first place, such expenditures are socially necessary, not socially wasteful. 157

As far as getting locked into an inferior standard, evidence from the marketplace again suggests that this may happen in the absence of any legal exclusionary right. ${ }^{158}$ In addition, historical evidence from the

154. See, e.g., M. Therese Flaherty, Field Research on the Link Between Technological Innovation and Growth: Evidence from the International Semiconductor Indusiny, 74 AM. ECON. REv., May 1984, at 67, 69 (papers \& proceedings) (patents give little monopoly power in the semiconductor industry); Katherine M. Hafner, The Knockoffs Head for a Knockdown Fight with IBM, Bus. WK., Dec. 21, 1987, at 112, 113 (Even with patent protection on a work, "competitors will match it-or come close.").

155. See Synercom Technology, 462 F. Supp. at 1013 n.5; Leslie Helm, IBM s "Clone Killers" Don 't Scare Phoenix Technologies, Bus. WK., Dec. 21, 1987, at 113, 113 (describing development of an IBM-compatible BIOS by Phoenix).

156. See Seither, supra note 114 , at 12.

157. Cf. Kepner-Tregoe, Inc. v. Carabio, 203 U.S.P.Q. (BNA) 124, 131 (E.D. Mich. 1979) ("To cite an extreme, how many ways may one describe how to draw a circle with a compass? To be sure, many outlandish methods using eccentric styles could be conceived. But there is no societal value in that."); see also Palmer, supra note 119, at 209-10.

158. See Paul A. David, CLIO \& the Economics of QWERTY; 75 AM. ECON. REv., May 1985, at 332, 336 (papers \& proceedings). Economic rationality does not always dictate results. The QWERTY keyboard remains despite proof that more efficient designs exist which would, for typists, repay the retraining investment within a few days. See id. at 332. Economically consistent rationales might still justify a refusal to switch to a more efficient standard, since typists may fear that retraining would lessen the transferability and marketability of their skills or manufacturers may fear that production of the more efficient design would reduce the total 
computer marketplace suggests little tendency of inferior standard adoption as a result of copyright. ${ }^{159}$ Smaller creative companies have been very successful in seeing their products adopted, either indirectly, through tying arrangements with larger firms which have substantial marketing power but lack innovative technology, or directly, by marketing a superior product.

Tying arrangements enabled Microsoft's operating system to become a standard in the personal computer field despite the company's small size at the time. ${ }^{160}$ Similarly, Intel's use of second-sourcing enabled it to capture a far more substantial part of the market than its manufacturing capabilities could have supplied. ${ }^{161}$

Even without tying arrangements, small firms with innovative and superior products can succeed despite competition from companies with far superior market power. The field of computer workstations, which is expected to be the next big product cycle in computers, provides a powerful example of this fact. ${ }^{162}$ Using reduced instruction set chips (RISCs), the smaller companies set the standards for workstation design and performance. ${ }^{163}$ Now IBM and DEC are following their lead. ${ }^{164}$ The chosen operating system (UNIX) for most workstations was developed by Bell Labs, known more for its technical ability than its brute marketing strength. ${ }^{165}$

Both of these methods of getting innovative products to the consumer illustrate the nature of the computer market. Since purchasers

level of demand for their products. See id. at 332-33. Note that the initial popularity of QWERTY arose from its use to teach the touch typing technique in the 1890 s, not as a result of any legal monopoly in the QWERTY keyboard. See id. at 334. Interestingly enough, the electronic word processor may solve this problem. A software interface can be used to convert the QWERTY keyboard to any other desired arrangement. Word processors can then take their converter with them and not have to worry about incompatible skills (though faster word processors may decrease the demand for word processors). Furthermore, a programmer who creates this software package has no concern about the total demand for word processors, but only cares about the demand for her program.

159. In fact, evidence suggests that producers who insist upon producing goods under a proprietary standard may fare poorly in the computer market. See, e.g., Susan M. Gelfond, IBM's Micro Channel Gets a Little Respect, Bus. WK., Mar. 20, 1989, at 156, 156-58; Leslie Helm, Can Apollo Stop Hurlling Toward Earth?, Bus. WK., Feb. 27, 1989, at 108; Mark Ivey \& Geoff Lewis, Compaq us. IBM: Peace Comes to Shove, Bus. WK., Mar. 13, 1989, at 132; Microsoft Hedges Its Bets, Bus. WK., Feb. 27, 1989, at 46.

72.

160. See Richard Brandt, The Billion-Dollar I'hiz Kid, Bus. WK., Apr. 13, 1987, at 68, 68-

161. See Wiegner, supra note 114 , at 158-60.

162. See Stuart Gannes, IBM and DEC Take on the Little Guys, ForTune, Oct. 10, 1988, at 108, 108; Robert D. Hof, Why MIIPs is the One to Beat, Bus. WK., Feb. 27, 1989, at 40, 40-41.

163. A conventional instruction set chip (CISC) will have hundreds of instructions that it directly recognizes. A RISC recognizes only the $20-30 \%$ of these instructions that are used most often. The smaller instruction set means that the RISC can do "less" but it can do it much faster than a CISC. See Mark Alpert, Why It's a RISC W'orth Taking, ForTunE, Oct. 10, 1988 , at 112.

164. See Gannes, supra note 162 , at $109,114$.

165. See Organisation for ECONOMic Co-operation and Development, supra note 122, at 45-46; Alpert, supra note 163, at 112; Alex Kozlov, Bell Labs" New Get-Tough Style, Bus. MONTH, Mar. 1988, at 37. 
of these products use them to improve productivity and to compete in the purchaser's own markets, purchasers will not tolerate obsolete or inferior equipment, but instead will update regularly. Thus, both of the first two theoretical concerns are undermined by the realities of the marketplace.

Dealing with the third concern, whether copyright will impede the production of future works, presents greater difficulty. Commentators argue that works of computer technology, because they are technology, progress in steps. ${ }^{166}$ Each work improves slightly on what has gone before. They argue that to provide a legal monopoly over any given work in the progression will impede this building process, yielding a lower total social value of the works than if the monopoly is not granted. ${ }^{167}$

The exact question presented is an empirical one ${ }^{168}$ : whether more and more highly valued works will be produced under a scheme where each designer must create anew or license each step in the progression, but is fully rewarded for the value she imparts to the work, or under a scheme where all designers as a whole are undercompensated for the creative elements they impart, but are free to copy as they see fit from the prior works of others. I think three responses can be made to the contention that an absence of copyright for works of industrial design is preferable.

First, consider the specific issue at hand. The design through written statements of the circuits on an ASIC, and the protection of these statements as copyrightable works and the circuits themselves as copies of the statements, presents no different considerations in terms of technological progress than does the design and protection of software programs as copyrightable works. For both, the use of prior works may make a specific task somewhat easier, but such use is neither necessary to the creation nor certain to improve the quality of the second work. Furthermore, the quantity and variety of software programs available today is considerable despite, or maybe because of, copyright protection. 169 While it is impossible to determine whether the quantity and variety would be greater without the protection, the 1980 amendments to the Copyright Act indicate that Congress's best guess is that protect-

166. See Chesser, supra note 143, at 258-59; Karjala, supra note 18, at 39-41; Spivack, supra note 127 , at 752, 754-55.

167. See Karjala, supra note 18, at 49, 95-96; see also Chesser, supra note 143, at 292-93.

168. See Giovanni Dosi, Sources, Procedures, and Microeconomic Effects of Innovation, $26 \mathrm{~J}$. ECON. LiteratuRE 1120, $1144-45$ (1988).

169. Spivack suggests that the current consolidation of, and high returns for, the software industry are a result of excessive legal protection. See Spivack, supra note 127, at 763 n.169. This is the exact sort of jump that cannot be made on the available evidence. Despite the market concentration and high returns, it remains uncertain whether higher social value will be generated under a system giving extensive protection to sof ware through copyright or under a system with less extensive protection. 
ing computer programs will prove the better alternative. ${ }^{170}$

As a general matter for all works of technology, the argument is certainly less convincing than these commentators would have you believe. All of them fail to meaningfully distinguish the creative process for technology from that employed in creating works of art or literature. ${ }^{171}$ Consider a novel or a motion picture. Despite possible short term quantity and cost advantages from permitting large segments of prior works to be copied into new movies or novels, we have decided to forego those short term advantages in the hope that copyright will encourage a greater production over the long term. ${ }^{172}$

Is there some qualitative difference in the creativity or the design process involved between creating a work of literature and a work of technology? In writing a note, I set a goal, perhaps of convincing my audience of the desirability of copyright protection for ASICs. I then craft together words and phrases, looking at their qualities and their texture, (hopefully) within the rules of grammar, to achieve a work that (perhaps) accomplishes that end. In designing a work of technology, perhaps a casing string for an oil well, I consider my materials, not words, but steel pipe and cement, look at their qualities, their tensile strength, size, weight, and a few others, and arrange my materials in a manner consistent with physical laws to achieve my objective. ${ }^{173}$ The conceptual difference between these two is significantly less than immediately apparent.

All the commentators can say to support their argument that the creative process is qualitatively different is that historically engineers have relied heavily on prior works, while authors have not. But that historical fact alone cannot prove the necessary point. ${ }^{174}$ Since authors are forbidden by copyright from direct copying and engineers are not, all that fact can prove is that in a system where we have already decided not to protect engineering works against this type of use, better engineering works may be produced more cheaply by copying from prior engineering works. This is a far cry from proving that, as an initial matter, a system which does not protect against this use produces better works than a system that does.

As my third and final response, I would like to free the engineer as a

170. Act of Dec. 12, 1980, Pub. L. No. 96-517, §10, 94 Stat. 3015, 3028 (codified as amended at 17 U.S.C. $\S \S 101,117$ (1987)).

171. All works build on works that go before them. See Sony Corp. of Am. v. Universal City Studios, 464 U.S. 417, 477 (1984) (Blackmun, J., dissenting); Zechariah Chafee, Jr., Reflections on the Law of Copyright: I, 45 CoLum. L. REv. 503, 511 (1945).

172. See, e.g., Harper \& Row, Publishers v. Nation Enters., 471 U.S. 539, 546 (1985); Sony Corp., 464 U.S. at 429; see also Twentieth Century Fox v. Aiken, 422 U.S. 151, 156 (1975); Mazer v. Stein, 347 U.S. 201, 219 (1954); United States v. Paramount Pictures, 334 U.S. 131, 158 (1948).

173. See generally J.A. "Jim" Short, Drilling and Casing Operations 303-51 (1983).

174. See Chesser, supra note 143, at 260 \& $n .63$ (universal copying of circuits); Karjala, supra note 18, at 39 (bridge example). 
designer from the "technician" restraints the commentators seek to bind her with and remind them that even with engineers, you get what you pay for. ${ }^{175}$ Each application of engineering principles to a new problem or situation involves creative energies. Looking at the physical laws and copying various items from past works provides no determinant, ideal solution. For any given task, there may be any number of equally satisfactory solutions. ${ }^{176}$ It is the engineer's task to look through the many possible solutions to find the one that seems best to her.

Furthermore, in looking at past works, the engineer must decide which elements should be copied into the new work, avoiding elements that were mistakes or unnecessary in the prior works. She must recognize the material differences in the conditions between the prior problems and the current one, modifying elements to conform fully to the current conditions. By definition, a better engineer will use the available information and materials to produce a work with a higher social value, while a poorer engineer may incorporate prior mistakes or fail to fully adjust elements of prior works to the new situation, leading to a work with comparatively lower, possibly negative, social value. ${ }^{177}$

If we refuse to protect these works to reward the engineer in proportion to the societal value of her work, the likely result is a lower quality of engineer and engineering works. The poor engineer merely copies from prior works, adding little in the way of social value, but receives a reward that reflects both the value of the prior works and his own comparatively meager contribution. He is being subsidized in his practice by efforts of prior engineers. Economically, this subsidy will create a greater supply of these engineers than would otherwise be present.

The better engineer will add significant social value to the prior works and is the one who will be subsidizing the poor engineers of tomorrow. This subsidy acts as a tax of sorts on her income, which economically results in a smaller supply of better engineers than would otherwise be present.

Finally, the failure to protect these works seeks to achieve the same works for less, the only certain result of which is to reduce salaries for engineers. Failure to protect treats the engineer as a technician, assuming that an engineer neither has nor needs creative talent. Both of these factors will tend to drive some who would have been engineers

175. See Chesser, supra note 143, at 288-89; Karjala, supra note 18, at 88 .

176. Consider the contests in engineering schools to build a paper airplane that flies furthest or a bridge from toothpicks that supports the greatest load. If the best solution were inherently determined by the available materials and natural laws, everyone should develop the same airplane, the same bridge. But the simple answer is that everyone does not.

177. See Paul Dvorak, How Does Good Engineering Go Bad?, MACHINE Design, Oct. 6, 1988, at 105. By negative social value, I am referring to bridges or buildings that collapse because of the engineer's failure to consider the environment of the work. Cf. Scouring Suspected in Failure, ENR, Apr. 6, 1989, at 19 (7 people died when a bridge collapsed). 
into other tasks-tasks which, while producing less social value, nevertheless are more highly compensated and more respected in society. ${ }^{178}$

Thus, the comparison becomes whether a bunch of undercompensated, mediocre engineers can, by copying elements from prior works, create new works that over the long run have a higher net social value than the new works created by a group of properly compensated, more talented engineers who license prior works or design from scratch as the situation demands. The choice we have made to protect through copyright other forms of creative works, especially software programs, seems to justify the protection of the set of statements and the resulting ASICs in the same manner. However, to ensure that copyright protection for this technology generates a net gain for society, courts must carefully circumscribe the scope of the monopoly.

\section{The idea-expression dichotomy.}

The key to successfully applying copyright to the set of statements and the resulting ASIC lies in recognizing that copyright protects the set of statements as a literary work. ${ }^{179}$ Therefore, the scope of protection must focus on the literary nature of the work. Accordingly, the idea-expression dichotomy should dictate the scope of protection, not the useful article limitation which governs pictorial, graphic and sculptural works.

Recall, however, that the successful application of the idea-expression dichotomy requires a determination of which elements are expression and which are idea. Neither idea nor expression is self-defining. ${ }^{180}$ Consequently, when courts determine which elements of a work to protect (expression) and which elements not to protect (idea), they are actually making a policy determination as to the scope of the monopoly required to produce the work in question. ${ }^{181}$

In applying the idea-expression dichotomy to the set of statements

178. Consider litigators, for example. Litigators create very little social value (the decisions that result from litigation create law, so they may somewhat increase the size of the pie). Instead, they concentrate on dividing up the existing pie. Their high salaries are a reflection of their value to the private parties who want a bigger share of the pie.

179. 17 U.S.C. \& 101 (1982). See also Whelan Assocs. v. Jaslow Dental Lab., 797 F.2d 1222, 1234 (3d Cir. 1986), cert. denied, 479 U.S. 1031 (1987); Apple Computer v. Franklin Computer Corp., 714 F.2d 1240, 1249 \& n.7 (3d Cir. 1983), cert. dismissed, 464 U.S. 1033 (1984). Most people do not buy software to read the code, but rather to convert a general purpose machine into a task-specific machine. Nevertheless, the useful article limitation can provide no useful guide in the area. All gate configurations are equally utilitarian, whether represented in source code, object code, or conventional hardware schematics. To that extent, the useful article limitation is useless to draw lines either between hardware and software or within any given program as to which elements should be protected.

180. Cf. Apple Computer, $714 \mathrm{~F} .2 \mathrm{~d}$ at 1253 (whether ideas and expression have merged is a metaphysical issue).

181. See, e.g., Herbert Rosenthal Jewelry Corp. v. Kalpakian, 446 F.2d 738, 742 (9th Cir. 1971) ("What is basically at stake is the extent of the copyright owner's monopoly-from how large an area of activity did Congress intend to allow the copyright owner to exclude others?"). 
and the resulting ASIC, a correct analysis of the two principles of copyright ${ }^{182}$ should determine which elements are idea and which are expression. To say that the work is an engineering work and that therefore the majority of its value must remain unprotected will not suffice. Furthermore, if the idea selected excludes most of the economic value of the work, that is a strong indication that the idea has been chosen incorrectly, and that we should rethink our policy analysis. In fact, if "engineering" work contains a greater portion of its value in the future uses of the work than traditional literary works, aspects of the work relating to the future value must receive greater, not less, protection in order for the work as a whole to capture the same percentage of its societal value. ${ }^{183}$

As a starting point, remember that all of the various forms of computer programs represent a system, i.e., a method of getting from point $A$ to point B. ${ }^{184}$ Courts long ago decided that the principles behind copyright justify excluding systems from protection; ${ }^{185}$ therefore, others must be free to travel the same route. Yet at the same time, subsequent authors are not free to use the original expression employed. The line between the system, or idea, and the expression is a troublesome one. ${ }^{186}$ To explore it, the courts have developed several doctrines, which reflect the underlying principles of copyright. These principles can be examined to help determine which elements in a work generally should be protected. For our work, three of these doctrines require careful consideration: a narrow range of protection for aspects that can only be expressed in a limited number of ways, merger for truly basic works, and no protection for expression dictated by external constraints.

Case law tells us that a work expressing an idea that may be expressed in only a limited number of ways will have a very narrow range

182. See text accompanying notes 113-151 supra.

183. To avoid creating incentives for investment in directions contrary to those indicated by the total social value of the work, the author's return as a percent of societal value should remain constant across the range of works protected by copyright.

184. Indeed, the definition of computer program requires that the work be capable of producing a result. 17 U.S.C. $\$ 101$ (1982).

185. See Baker v. Selden, 101 U.S. 99 (1879); see also 17 U.S.C. § 102(b) (1982); text accompanying notes 106-112 supra.

186. The levels-of-abstractions approach suggested by Learned Hand has proven quite durable in this area (or at least the words by which he described it have). See Nichols v. Universal Pictures Corp., 45 F.2d 119 (2d Cir. 1930), cert. denied, 282 U.S. 902 (1931).

Upon any work, and especially upon a play, a great number of patterns of increasing generality will fit equally well, as more and more of the incident is left out. The last may perhaps be no more than the most general statement of what the play is about, and at times might consist only of its title; but there is a point in this series of abstractions where they are no longer protected, since otherwise the playwright could prevent the use of his "ideas," to which, apart from their expression, his property is never extended.

Id. at 121. 
of protection, perhaps prohibiting only near-verbatim copying. ${ }^{187}$ Particularly, the courts will provide a limited range of protection in areas where use of some aspects of a copyrighted work is critical to the creation of future works. Thus, a copyright in a musical work will not cover rhythm or harmony, because of their fundamental nature; music as we know it cannot be expressed without resort to these building blocks. ${ }^{188}$ Similarly, copyright does not protect basic shapes in artwork, ${ }^{189}$ the layout of streets on a city map, ${ }^{190}$ facts in a news story, biography, scientific or historical work, ${ }^{191}$ game rules, or instructions for useful articles. ${ }^{192}$

At the extreme, when there is only one way to express an idea, the idea and the expression merge, and the work receives no copyright protection. Since both "idea" and "expression" are merely words used to cover a policy determination as to the appropriate extent of copyright protection, "merger" must represent a determination that to protect this work would provide a monopoly broader than that Congress intended. 193 Thus, basic designs and gates would not be protected because, like basic dance steps, to protect them would provide too broad

187. See Landsberg v. Scrabble Crossword Game Players, Inc., 736 F.2d 485, 488 (9th Cir. 1983), cert. denied, 469 U.S. 1037 (1984).

188. See, e.g., Northern Music Corp. v. King Record Distrib. Co., 105 F. Supp. 393, 400 (S.D.N.Y. 1952).

189. See, e.g., Franklin Mint Corp. v. National Wildlife Art Exch., Inc., 575 F.2d 62, 65

(3d Cir. 1978) (artwork), cert. denied, 439 U.S. 880 (1978); I P. GoldsteIN, supra note 4, § 2.11.

190. Moore v. Lighthouse Publishing Co., 429 F. Supp. 1304, 1310 (S.D. Ga. 1977)

("The streets, squares and various historic landmarks in 'Old Savannah' cannot be exclusively appropriated" by a map portraying them.).

191. See, e.g., Worth v. Selchow \& Righter Co., 827 F.2d 569, 572-73 (9th Cir. 1987), cert. denied, 108 S. Ct. 1271 (1988); Hoehling v. Universal City Studios, 618 F.2d 972, 979 (2d Cir. 1980), cert. denied, 449 U.S. 841 (1980); Rosemont Enters. v. Random House, Inc., 366 F.2d 303, 310 (2d Cir. 1966), cert. denied, 385 U.S. 1009 (1967); 1 P. Goldstern, supra note 4, $\S 2.14(4)$.

192. See Landsberg, 736 F.2d at 488-89; Morrissey v. Proctor \& Gamble Co., 379 F.2d 675, 678-79 (1st Cir. 1967); Decorative Aides Corp. v. Staple Sewing Aides, 497 F. Supp. 154, 157 (S.D.N.Y. 1980), aff'd, 657 F.2d 262 (2d Cir. 1981); Freedman v. Grolier Enters., 179 U.S.P.Q. (BNA) 476, 478-79 (S.D.N.Y. 1973), aff'd, 495 F.2d 1367 (2d Cir. 1974).

193. Cf. Herbert Rosenthal Jewelry Corp. v. Honora Jewelry Co., 509 F.2d 64, 65-66 (2d Cir. 1974) (a jewelled pin in the shape of a turtle with ten jewels on its back is an idea, and only expression beyond that idea is protected); Herbert Rosenthal Jewelry Corp. v. Kalpakian, 446 F.2d 738, 742 (9th Cir. 1971) (in dealing with an alleged infringement of the copyright on a jewelled bee pin, a finding of infringement would have covered basically all jewelled bee pins, providing too broad of a monopoly; therefore the court indicated that "on this record the 'idea' and its 'expression' appear to be indistinguishable"). At least one commentator believed that true merger should never occur. See 1 M. Nimmer \& D. Nimmer,, supra note 5, $\$ 2.18(c)(2)$ ("factually erroneous to conclude that there is any system or method which can be performed by the use of only one particular form of written expression"). However, that is irrelevant to whether policy considerations indicate that a finding of infringement will grant the author too broad of a monopoly. Many courts have focused on the number of ways to express an idea. See, e.g., Whelan Assocs. v. Jaslow Dental Lab., 797 F.2d 1222, 1240 (3d Cir. 1986), cert. denied, 479 U.S. 1031 (1987); M. Kramer Mfg. Co. v. Andrews, 783 F.2d 421, 436 (4th Cir. 1986); Apple Computer v. Formula Int'l, 725 F.2d 521, 525 (9th Cir. 1984); Apple Computer v. Franklin Computer Corp., 714 F.2d 1240, 1253 (3d Cir. 1983), cert. dismissed, 464 U.S. 1033 (1984); E.F. Johnson Co. v. Uniden Corp. of Am., 623 F. Supp. 1485, 1502 (D. Minn. 1985). This line of analysis is proper only in that multiple forms of expression indicate 
a monopoly given their importance to the creation of future works. ${ }^{194}$ For these works, merger is clearly appropriate. ${ }^{195}$

To the extent that external constraints dictate a particular feature in a copyrighted work, that feature may be copied without infringing the copyright. ${ }^{196}$ External constraints may require the second work to be substantially similar to the original work to be competitive in the market. Such constraints include engineering and economic considerations, ${ }^{197}$ the preferences of the consuming public, ${ }^{198}$ external compatibility requirements, ${ }^{199}$ and the nature of the work itself. ${ }^{200}$ Thus, in building a tower with a spherical structure on top, those elements of the design which are dictated by engineering and economic considerations cannot be protected by copyright. ${ }^{201}$ Similarly, in creating a program for individuals involved in cotton marketing, those elements "dictated by the externalities of the cotton market" are not

that a finding of infringement can eliminate copying without providing an exclusive right to the market.

194. See Hoehling v. Universal City Studios, 618 F.2d 972, 974 (2d Cir. 1980), cert. denied, 449 U.S. 841 (1980). In the context of fictional work based on historical theories, the court held that copyright does not extend to historical facts. "The rationale for this doctrine is that the cause of knowledge is best served when history is the common property of all, and each generation remains free to draw upon the discoveries and insights of the past." Id. Going further, the court concluded that the scope of copyright must be limited "[t]o avoid a chilling effect on authors who contemplate tackling an historical issue or event." Id. at 978; $f$. Warner Bros. v. American Broadcasting Co., 720 F.2d 231 (2d Cir. 1983).

It is a fundamental objective of the copyright law to foster creativity. However, that law has the capacity both to augment and diminish the prospects for creativity. By assuring the author of an original work the exclusive benefits of whatever commercial success his or her work enjoys, the law obviously promotes creativity. At the same time, it can deter the creation of new works if authors are fearful that their creations will too readily be found to be substantially similar to preexisting works.

Id. at 240.

195. Even for basic dance steps, merger is not metaphysically required, since a higher level of abstraction is available for which these items would be expression. For example, basic dance steps might be an expression of the idea of social recreation, for which, in addition to dance, various sports, conversation, people watching, beer drinking, and any number of other possibilities would constitute expression. Cf. IWhelan, 797 F.2d at 1236 ("everything that is not necessary to that purpose or function would be part of the expression of the idea") (emphasis in original). 196. See note 106 supra.

197. See Wickham v. Knoxville Int'l Energy Exposition, 555 F. Supp. 154, 156 (E.D. Tenn. 1983), aff'd, 739 F.2d 1094 (6th Cir. 1984).

198. See Plains Cotton Coop. v. Goodpasture Computer Serv., 807 F.2d 1256, 1262 (5th Cir.), cert. denied, 108 S. Ct. 180 (1987).

199. See NEC Corp. v. Intel Corp., No. C-84-20799-WPG, slip op. at 34 (N.D. Cal. Feb. 6, 1989); Synercom Technology v. University Computing Co., 462 F. Supp. 1003, 1013-14 (N.D. Tex. 1978); cf. E.F. Johnson Co. v. Uniden Corp. of Am., 623 F. Supp. 1485, 1502-03 (D. Minn. 1985) (elements necessary for compatibility not protected); Harcourt, Brace \& World, Inc. v. Graphic Controls Corp., 329 F. Supp. 517, 525 (S.D.N.Y. 1971) (narrow originality range in answer sheet design severely limits copyright protection; nevertheless, direct evidence of copying merits finding of infringement). But cf. Apple Computer v. Franklin Computer Corp., 714 F.2d 1240, 1253 (3d Cir. 1983) (compatibility is a commercial objective and not considered in defining the idea of a work), cert. dismissed, 464 U.S. 1033 (1984).

200. Q-CO Indus. v. Hoffman, 625 F. Supp. 608, 616 (S.D.N.Y. 1985) (modules that are an inherent part of any prompting program are not protected).

201. Wicham, 555 F. Supp. at 156. 
protected. ${ }^{202}$

The common thread to all three of these limitations is that the author should not be rewarded for value she did not create. They are a reflection of the desire to "assure contributors to the store of knowledge a fair return for their labors." 203 To be "fair," a return must reflect the value to society of the intellectual labor imparted to the work by the author, without rewarding the author for value she did not impart.

Consider an input format for a program ${ }^{204}$ or an optical scanning machine. ${ }^{205}$ The program or scanning machine will constrain the design of the input format, requiring that the data to be input be placed on a certain type of input media and arranged in a certain manner. If our definition of idea did not permit another to copy those elements of the input format necessary to communicate successfully with the program or scanner, a member of the public desiring to use the scanner or program would have to use this particular input format. As a result, the author of the input format could extract some portion of the value of the program or computer, which would reward her for the intellectual efforts of another. Such a result would redistribute the returns between the author of the input format and the developer of the scanner or program, giving the input format author a larger share, which results in an overinvestment in the format and an underinvestment in the program or computer. ${ }^{206}$

Aspects of computer programs that impart value as a result of another's efforts, or as a result of external constraints, should not be protected by copyright. For example, while perhaps responsible in a butfor sense, an author of an operating system should not be entitled to receive compensation through copyright for application programs written by others to run on his system. ${ }^{207}$ Nor should the copyright in the operating system protect aspects of the microprocessor with which it is used. ${ }^{208}$ Therefore, to determine whether an element common to both the original operating system and a later, functionally equivalent work indicates infringement, a court must ask whether the element is reason-

202. Plains Collon Coop., 807 F.2d at 1262.

203. Harper \& Row, Publishers v. Nation Enters., 471 U.S. 539, 546 (1985); see also 1 P. GoldSTEIN, supra note $4, \S 7.1 .2$.

204. Synercom Technology, 462 F. Supp. at 1013-14 (restricting copyright protection for an input format for a program).

205. Harcourt, Brace $\mathcal{E}$ World, Inc., 329 F. Supp. at 525 (restricting copyright protection for an input format for an optical scanner).

206. See text accompanying notes 146-151 supra.

207. The but-for causality is insufficient because the later authors would have produced their works for some other system if the original author's were not available. But see Apple Computer v. Franklin Computer Corp., 714 F.2d 1240, 1253 (3d Cir. 1983) (desire to create a compatible system is a commercial object and "does not enter into the somewhat metaphysical issue of whether particular ideas and expressions have merged"), cert. dismissed, 464 U.S. 1033 (1984). $6,1989)$.

208. See NEC Corp. v. Intel Corp., No. C-84-20799-WPG, slip op. at 34 (N.D. Cal. Feb. 
ably necessary, given the constraint of being compatible with both the application programs and the microprocessor. ${ }^{209}$ If it is, then identity between the elements provides no indication of infringement. This test will limit copyright protection for specific elements, such as the instruction set for operating systems, as well as for general elements, such as structure, sequence and organization, whenever protecting those elements would enable the author to garner the rewards for societal value she did not create. 210

By properly applying this principle, gate configurations, whether created through conventional software design or through traditional hardware design, can be protected under the copyright system in a manner providing the proper level of incentives and direction for investment, without unduly hindering the creation of new works. While line drawing will still be required, it should focus on incentives rather than talismanic words. Such a focus reduces uncertainty in investment by shifting the critical question from whether a work is hardware or software to whether a work is sufficiently original. While a work falling on the border between hardware and software may have cost millions to create, ${ }^{211}$ a work falling on the border between original and nonoriginal will likely have required a much smaller investment. ${ }^{212}$ Furthermore, a line drawn on the basis of originality will remain valid as computer technology progresses.

\section{ConCLUSION}

Copyright must continually adapt to recognize new forms of expression and to protect expression that comes to be recognized as creative. The design of ASICs involves elements of both.

Keeping in mind that the medium is not the message, products in computer technology that embody the same level of intellectual creativity, are functionally interchangeable, and face the same risk of piracy through inexpensive duplication, all deserve the same form of protection. Given the nature of computer technology and its market, copy-

209. See, e.g., Plains Cotton Coop. v. Goodpasture Computer Serv., 807 F.2d 1256, 1262 (5th Cir.) ("[M] any of the similarities between the GEMS and Telcot programs are dictated by the externalities of the cotton market."), cert. denied, $108 \mathrm{~S}$. Ct. 80 (1987); Q-CO Indus. v. Hoffman, 625 F. Supp. 608, 616 (S.D.N.Y. 1985) ("[T] he same modules would be an inherent part of any prompting program.").

210. See, e.g., Wickham v. Knoxville Int'l Energy Exposition, 555 F. Supp. 154, 156 (E.D. Tenn. 1983) ("uncontroverted evidence that economic and engineering considerations dictated the height and structural steel design of the Sunsphere tower"), aff $d, 739$ F.2d 1094 (6th Cir. 1984).

211. See Simpson, supra note 17 , at 122 (costs for semicustom integrated circuits range from $\$ 1.8$ million to $\$ 20$ million for a production run of 50,000 chips, each with 10,000 gates).

212. Compare Alva Studios v. Winninger, 177 F. Supp. 265, 266-68 (S.D.N.Y. 1959) (exacting scale model of public domain statute is original), with Past Pluto Prods. Corp. v. Dana, 627 F. Supp. 1435, 1437, 1443 (S.D.N.Y. 1986) (flat foam hat based on the Statue of Liberty not sufficiently original). 
right protection seems the most appropriate. Only copyright can encourage works that entail only marginal advances over, and slight differences from, prior works.

Most importantly, only by eliminating differences in the nature of protection and the resulting incentives for investment between software and hardware can the value to society determine the appropriate levels of investment in each. To do otherwise runs the significant risk of stifling innovation when the resulting product falls on the wrong side of the copyright line. 